\title{
Militarne wizerunki przypisywane św. Jerzemu-smokobójcy i ich mitologiczno-religijne konotacje (na przykładzie wczesnośredniowiecznych zawieszek z Europy Środkowo-Wschodniej)
}

\author{
Military Images Attributed to St. George the Dragon-slayer and their \\ Mythological and Religgious Connotations (on the Example of Early Medieval \\ Pendants from Central and Eastern Europe)
}

\begin{abstract}
Abstrakt: Artykuł stanowi próbę interpretacji treści ikonograficznych i znaczeniowych zakodowanych $\mathrm{w}$ tarczowatych zawieszkach $\mathrm{z}$ konnymi wizerunkami przypisywanymi św. Jerzemu-smokobójcy (Ruś-k. XI - pol. XIII w.; Polska - poł. XII - pierwsza pol. XIII w.; Łotwa-k. XII-XIVw.). Zgodnie z kanonami ikonografii chrześcijańskiej miały one ukazywać zarówno moc Bożą, jak i potęgę świętego. Jednocześnie ich treść sięga głębszych pokładów znaczeniowych, związanych
\end{abstract}

$\mathrm{z}$ archetypicznym odwzorowaniem kosmicznego pojedynku pomiędzy pierwotnymi siłami identyfikowanymi z chaosem i destrukcją a dążącymi do zaprowadzenia ładu społeczno-cywilizacyjnego. Przedmioty te mogły być świadectwem zachodzących procesów chrystianizacyjnych, ale też jednocześnie pełnić funkcję amuletu. Kontekst grobowy wskazuje, że w tej podwójnej roli zawieszki były wykorzystywane przez kobiety. Ich adresatami i odbiorcami hipotetycznie mogli być też wojownicy.

Słowa kluczowe: wczesne średniowiecze, broń drzewcowa, św. Jerzy-smokobójca, wyposażenie grobowe, zawieszki ze świętymi wojownikami, motyw węża-smoka

Ikonograficzny motyw zmagań bóstwa gromowładnego, odpowiedzialnego za ład kosmiczny, ze swym chtonicznym adwersarzem, gadzim monstrum, uosabiającym chaos i destrukcję, ma odległą i ugruntowaną mitologicznie genezę. W wersji schrystianizowanej w rolę pogromców zła wcielali się święci wojownicy i herosi, przejmując cechy i atrybuty dawnych bogów lub wręcz stając się ich ideologicznymi kontynuatorami (m.in. Myts'ko 1998: 30; Shevelev 2005; Szczepański 2010: 9; Katičic 20II: 82-84; Szczepanik 20I5: 182; Tyanina 20I8: 63) ${ }^{1}$. Owi smoko- czy

1 Wzorcowym typem takiego kulturowego herosa jest Ilja Muromiec, opiewany za swe bohaterskie czyny w ruskich bylinach, jak również w bajkach, legendach i pieśniach (zob. Astakhova 1958; Kozlovskiy 2016). 
wężobójcy obrazowani byli jako wojownicy konni lub spieszeni, na ogół z włócznią wymierzoną w wijącą się na ziemi bestię. Znalazło to wyraz w bardzo licznych realizacjach artystycznych pojawiających się już od IV w., zarówno o skali monumentalnej (freski, płaskorzeźby), jak też niewielkiej o charakterze sztuki użytkowej (np. monety, pieczęcie, ozdoby). Na wyróżnienie zasługują też inne wyroby drobnej metaloplastyki, zwłaszcza wczesnośredniowieczne tarczowate zawieszki z konnymi wizerunkami, na ogół przypisywanymi św. Jerzemu.

Przedmioty te najczęściej odkrywane są na ziemiach dawnej Rusi, zwłaszcza na terenie dzisiejszych Rosji i Ukrainy (np. Sedova 2006; Stanyukovich 20Ir; Savyts'kyy, Svintsshch'kyy 2013; Churakova 2016; 2017; Kononovich 2013; Sobolev 2017a; 2017b; 2019). Znaczną ich koncentrację stwierdzono również na Łotwie, gdzie ograniczały się do obszaru łatgalskiego. Jak dotąd zarejestrowano tam I4 egzemplarzy pochodzących z ośmiu stanowisk (Spirgis 2019). Zbiór liczący dziesięć okazów odnotowano ponadto w granicach administracyjnych współczesnej Polski. Odkryto je na cmentarzyskach w Dołubowie, pow. siemiatycki (4 egz.) i Święcku-Strumianach, pow. wysokomazowiecki (r egz.), a także na terenie wczesnomiejskiego ośrodka w Gdańsku, pow. loco (2 egz.), na grodziskach w Jeglińcu, pow. sejneński (I egz.) i w Drohiczynie, pow. loco (I egz.) oraz na podgrodziu we Wrocławiu-Ostrowie Tumskim, pow. loco (I egz.).

Odmienności w sposobie ujęcia świętego wojownika na omawianych zawieszkach pozwalają wyodrębnić szereg ikonograficznych ujęć. Znalazło to odzwierciedlenie w podjętych w literaturze przedmiotu próbach typologicznego opracowania tych zabytków (zob. klasyfikacje w Sedova 2006; Stanyukovich 2011: 22-25; Sobolev 2017a). Również okazy pochodzące z Polski poddano analizie uwzględniającej różnice w ukazaniu postaci świętego. Przeprowadziła ją J.Żółkowska, dzieląc materiał na trzy podstawowe grupy, przy czym ostatnia (ujęcie popiersia) ma dwa warianty (Źółkowska 20I2; 2016).

Nie wdając w szczegółowe omawianie poszczególnych klasyfikacji i typów, trzeba zaznaczyć, że z punktu widzenia niniejszej pracy najbardziej interesujące są przedstawienia, na których święty wojownik pojawia się na koniu, z włócznią trzymaną w ręku i skierowaną ku rozciągniętej na ziemi bestii.

W opracowaniu J.Żółkowskiej egzemplarze spełniające takie kryteria ikonograficzne zostały włączone do grupy I, najliczniej reprezentowanej wśród omawianych znalezisk z Polski. Obejmuje ona wizerunki konnego wojownika (prawdopodobnie św. Jerzego) ${ }^{2}$ walczącego z wężem, przy czym charakterystyczne jest tu

2 W przypadku, gdy wizerunek świętego wojownika pozbawiony jest inskrypcji przy próbie jego imiennej identyfikacji zawsze pojawia się niebezpieczeństwo pomyłki, szczególnie gdy dotyczy to niewielkich wyrobów (zob. Musin 2007: 150-152). Na problem ten w odniesieniu do rozpatrywanych zawieszek zwróciła uwagę J. Żółkowska, uznając że w przypadku 


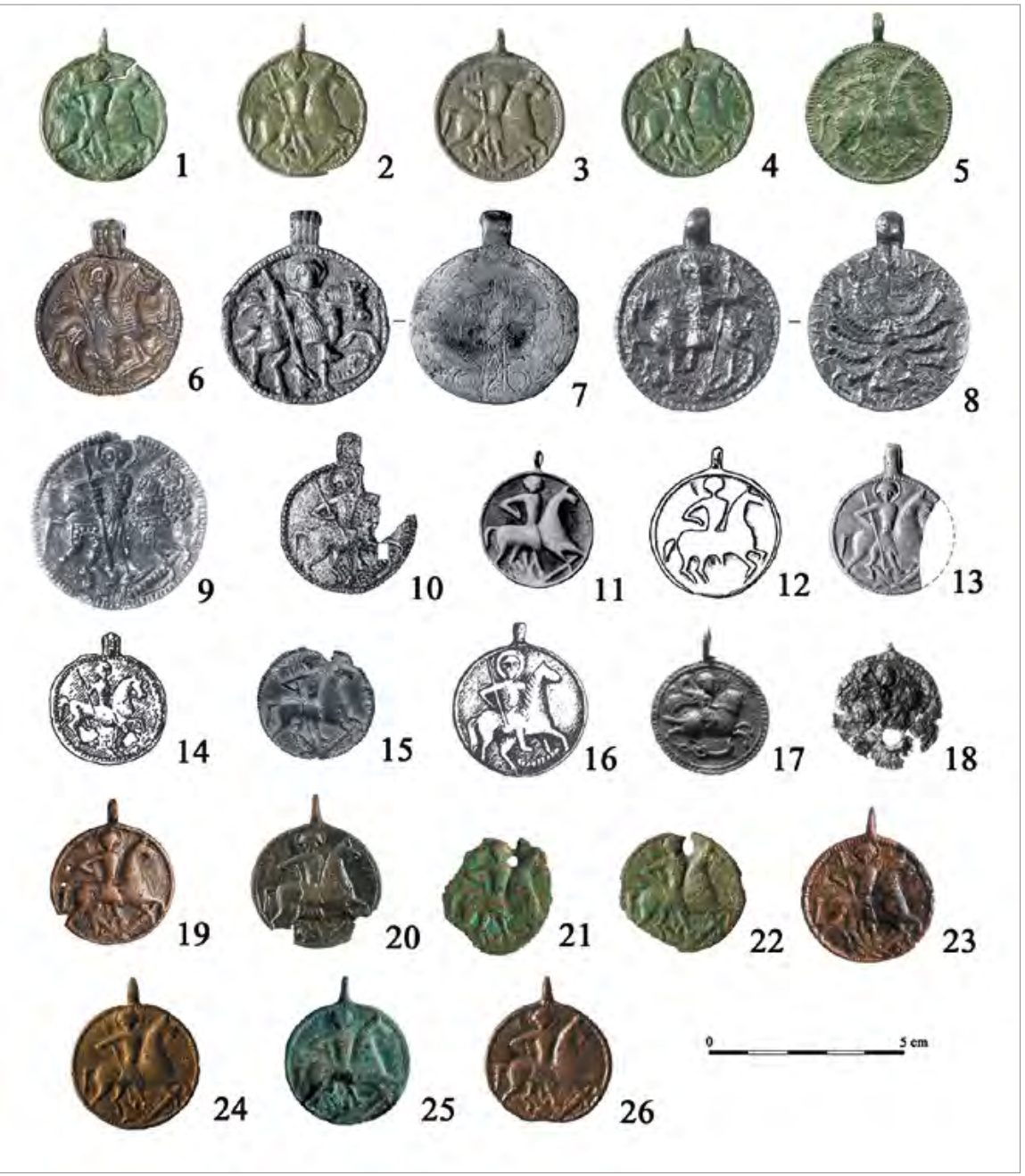

Ryc.1. Zawieszki przypisywane św. Jerzemu z Polski (I-6), Rosji (7-I4), Białorusi (I5-16), Ukrainy (I7-18) i Łotwy (19-26).

I-4 - Dołubowo (wg Żółkowska 20I2: ryc. 2:a-f); 5 - Święck-Strumiany (wg Żółkowska 20I2: ryc. 2:e); 6 - Wrocław (wg Żółkowska 20I2: ryc. 2:f); 7-IO - Nowogród (wg Sobolev 20I7a: ryc. 2:I-4); II - Nikolayevskoye (wg Sobolev 2017a: ryc. 2:I4); I2 - Kursk (wg Sobolev 2017a: ryc. 2:13); I3 - Region smoleński (wg Sobolev 20I7a: ryc. 2:I7); I4 - Serensk (wg Sobolev 20I7a: ryc. 2:8); I5 - Volkovysk (wg Sobolev 20I7a: ryc. 2:12); I6 - Drisvyaty (wg Sobolev 20I7a: ryc. 2:II); I7-I8 - Gorodishche (wg Churakova 20I7: ryc. I:I-2); I9 - Škilbenu Dañilovka (wg Spirgis 20I9: ryc. I:3); 20-22 - Kristapini (wg Spirgis 20I9: ryc. 2:I, 4:4-5); 23 - Asote (wg Spirgis 20I9: ryc. 2:2); 24 - Raunas kapusils (wg Spirgis 20I9: ryc. 2:3); 25 - Jaunpieblga (wg Spirgis 2019: ryc. 2:4); 26 - Vecpiebalgas Vecraskumi (wg Spirgis 20I9: ryc. 2:5). Oprac. T. Kurasiński. 
prawostronne ujęcie jeźdźca. Większosśc okazów to znaleziska grobowe. Cztery zawieszki w różnym stanie zachowania odkryto w grobie nr 49 na cmentarzysku z pochówkami w obudowach kamiennych w Dołubowie. Są niemal identyczne, a dwie z nich mogły nawet pochodzić z jednej matrycy (ryc. I: I-4). Najprawdopodobniej, wraz paciorkami szklanymi i zawieszką odlaną z brązu z wizerunkiem Matki Boskiej Orantki ${ }^{3}$, weszły w skład kolii. Grób może pochodzić z pierwszej połowy XIII w. (Źółkowska 20I6: 260, 261, 269). Zbliżony do powyższych zawieszek jest okaz ze Święcka-Strumian (ryc. I: 5). Znaleziono go w grobie nr 48, określonym jako kobiecy (wiek osobnika juvenis). Także w tym przypadku zawieszka razem ze szklanymi paciorkami tworzyła kolię. W jamie grobowej znajdowały się ponadto dalsze liczne ozdoby i dwa noże (Jaskanis 1999: 84: ryc. 46:3; 2008: 205, 312, ryc. 54, tabl. LXV:6). Górną granicę chronologiczną dla tego pochówka wyznacza początek XIII w. (Źółkowska 20I6: 263, 269) ${ }^{4}$. Natomiast zawieszka z Wrocławia różni się od powyższych egzemplarzy wielkością, budową uszka i detalami ikonograficznymi (ryc. I: 6). Odkryto ją w warstwie datowanej na połowę XII w. (Źółkowska 2016: 260-26I, ryc.2:f).

Egzemplarze ze świętym jeźdźcem i smokiem-wężem znane są przede wszystkim z północnych i północno-wschodnich ziem ruskich (głównie Ruś Włodzimiersko-Suzdalska). Na obszarach południoworuskich pojawiają się znacznie rzadziej (Źółkowska 2016: 273, ryc. 4 - mapa; Sobolev 2017a: 54I, ryc. I - mapa; Churakova 2017)5 (ryc. I: 7-18). Fakt odkrycia w Nowogrodzie Wielkim (ryc. I: 7-10) kilku takich egzemplarzy może nawet sugerować, iż to właśnie tam odbywała się produkcja zawieszek należących do grupy I (Źółkowska 2016: 273). Stamtąd znane są egzemplarze z najdokładniej oddanymi szczegółami wyobrażeń świętego jeźdźca. Chodzi zwłaszcza o dwa najwcześniej stratygraficznie datowane zmeeviki (xI - połowa XII w.), wyróżniające się wysoką jakością wykonania (ryc. I: 7-8). Prawdopodobnie więc to wyroby nowogrodzkie stały się prototypami czy modelami dla innych okazów tej serii, dzielonych przez V.Yu. Soboleva na dwa warianty ze względu na wielkość, sposób opracowania i stopień szczegółowości przedstawień (Sobolev 2017a: 539-540,

braku napisu najbardziej wiarygodne wizerunki św. Jerzego znajdują się na okazach grupy I z konnymi wojownikami walczącymi z bestią (Źółkowska 2012: 198; 2016: 272-273; zob. także Ters'kyy 2016: 63).

3 Szczegółowo na temat tego zabytku zob. Żółkowska 2017.

4 We wcześniejszej pracy J.Żółkowska wskazywała na pierwsze dziesięciolecia XIII w. (Żółkowska 2012: 196).

5 Dla tej części Rusi zdecydowanie bardziej charakterystyczne są zawieszki z wizerunkiem konnego wojownika trzymającego w lewej dłoni włócznię wzniesioną ku górze (Sedova 2006: 245; Churakova 2016: 368, ryc. 3 - mapa; Ters'kyy 2016: 64-65; Żółkowska 2016: $263-264$, ryc. 8 - mapa). 


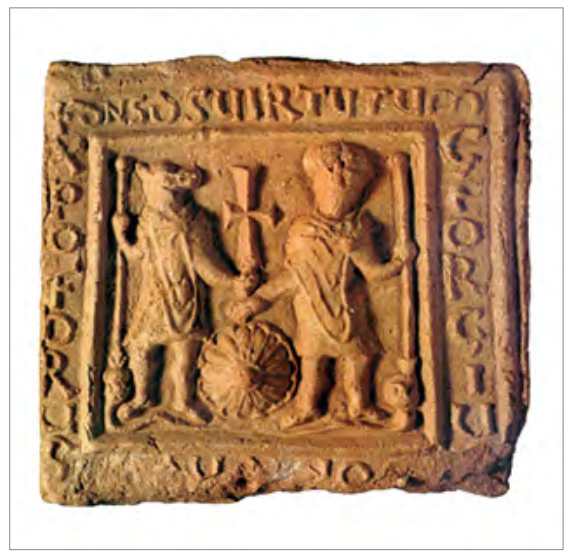

Ryc.2. Terakotowa ikonka ze św. Jerzym i św. Krzysztofem z Vinicy (Macedonia), v-VI w. (wg Gorgievski 20I2: ryc. I). Oprac. T. Kurasiński.
543, ryc. 2: I-2; 2017 b: 32-34, ryc. I:I-2; zob. także Sobolev 2019: 434). Nowogród jawiłby się tym samym jako ośrodek, z którego została zapoczątkowana dystrybucja tego rodzaju zawieszek. Jednakże obecność w rozpatrywanej grupie, zarówno egzemplarzy będących starannie opracowanymi odlewami, jak też o niskim jakościowo poziomie wykonawczym, z ledwie dostrzegalną sylwetką świętego jeźdźca, czy wręcz technologicznie wadliwych, stawia pod znakiem zapytania istnienie jednego tylko centrum produkcyjnego dla całej grupy zawieszek tego samego typu (Sobolev 2017a: 544; 2019: 431). Według A.Yu. Churakovej wszystkie znane dziś zawieszki z przedstawieniami św. Jerzego (z inskrypcjami) wiązać należy z terenami południoworuskimi. Ich wykonawcy przypuszczalnie inspirowali się dziełami mistrzów kijowskich (Churakova 2017: 613).

Bardzo liczny zespół analogicznych znalezisk pochodzący z Łotwy (ryc. I: 19-26) skłania do postawienia pytania o możliwość wykonywania ich w lokalnych warsztatach, choćby jako repliki egzemplarzy importowanych (Źółkowska 20ı6: 273). Na ogół jednak wiąże się je z działalnością chrystianizacyjną prowadzoną z Połocka i Pskowa (Źółkowska 20ı6: 274, przyp. 48). Natomiast w odosobnionej opinii R. Spirgisa naśladują one jakieś przedstawienie, które powstato pod wptywem tacińskim. Oddając bowiem aktualne realia zachodniej sztuki wojskowej (dosiad konia, uchwycenie włóczni) ${ }^{6}$, stanowią zaprzeczenie kanonicznej i wysoce tradycjonalistycznej sztuki ruskiej. Jednakże same w sobie zawieszki te nie mogą być kojarzone z łacińskim chrześcijaństwem, gdyż na Zachodzie nie było tradycji noszenia ikon (Spirgis 2019: 331).

Z kolei wszystkie zawieszki z motywem świętego wojownika z terenu Polski, w tym także okazy ze sceną zabijania węża-smoka, ze względu na niewielką ich liczbę, należy uznać za wyroby obce, najprawdopodobniej ruskie (Źółkowska 2016: 274).

Jako całość metryka „polskiej” grupy I zawieszek przypada na okres między połową XII a pierwszą połową XIII w. Kluczowe jest tu datowanie analogicznej zawieszki z Nowogrodu Wielkiego, odkrytej w warstwie datowanej

\footnotetext{
6 Por. przyp. 7.
} 


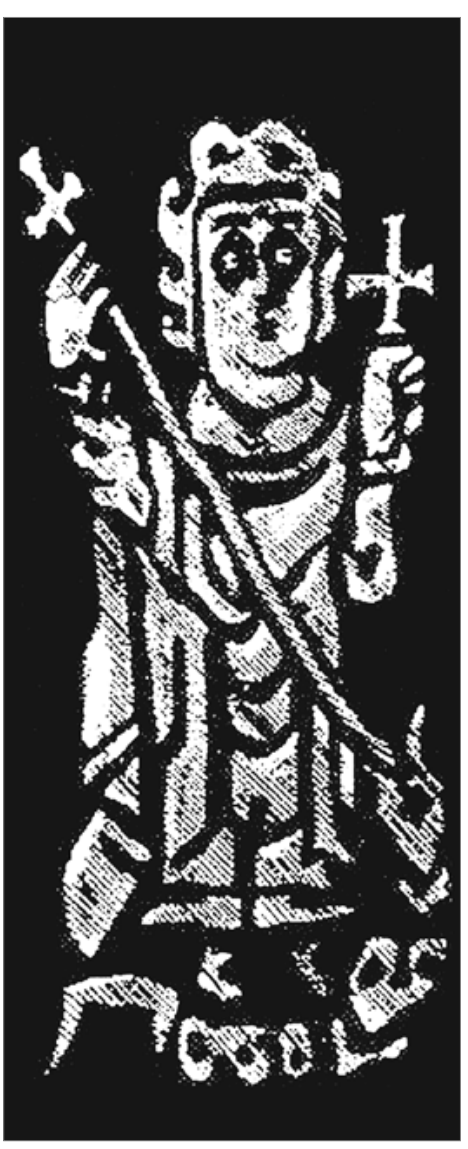

Ryc. 3. Koptyjska tkanina ze św. Jerzym z Achminu (Egipt), koniec IV-V w. (wg Atanasov 20or: ryc. I). Oprac. T. Kurasiński. dendrochronologicznie na lata II34-II6I (ryc. I: Io) (Sedova 1981: 62, ryc. 20:11; 2006: 245, 250 [nrI2]; Żółkowska 2012: 196; 2016: 269, 27I). Stamtąd zresztą pochodzą najstarsze okazy omawianego rodzaju, których datowanie potwierdzone jest stratygraficznie (koniec XI - połowa XII w.), natomiast w swej podstawowej masie chronologię okazów z Rusi określa się na drugą połowę XII - połowę XIII stulecia (Sobolev 2017a: 542-543; 2019: 430, 434). Według ostatnich ustaleń na terenie Łotwy analogiczne zawieszki pojawiły się nie wcześniej niż pod koniec XII stulecia i były używane do końca XIV w. (Spirgis 20I9: 32I-329, 332).

Nie wiadomo jednak, jak długo zawieszki pozostawały w obiegu. Od momentu powstania poszczególnych okazów do ich zdeponowania mogło upłynąć nawet kilkadziesiąt lat (Źółkowska 20I6: 274). Hipotetycznie można założyć, że podlegały one dynamicznym procesom wymiany, przekazywania i dziedziczenia. Na dłuższą cyrkulację często wskazuje niezbyt korzystny stan zachowania (wytarcia, ubytki), zdarza się też perforacja.

Jeśli istotnie na zawieszkach mamy do czynienia z wizerunkami św. Jerzego z Kapadocji, warto zaznaczyć, że święty ten († około 303 r.), patron rycerstwa, pasterzy i rolników, początkowo (VI w.) czczony był głównie za

7 V.Yu. Sobolev zwraca uwagę na różnice w sposobie trzymania i posługiwania się włócznią oraz dosiadu konia, które stanowią ikonograficzne odzwierciedlenie zmian w taktyce prowadzenia walki konno i zachowania jeźdźca zapoczątkowanych w XII stuleciu. Drzewce trzymane są pod pachą, nogi zaś są wyciągnięte w strzemionach zaopatrzonych w długie puśliska (szczegółowa analiza w Sobolev 2017b: 43-44; zob. także Churakova 2017: 613; Spirgis 2019: 330-331). Przekłada się to również na przyporządkowanie chronologiczne samych zabytków. Na temat sposobu przedstawiania rzędu końskiego w odniesieniu do wizerunków świętych wojowników, w tym także św. Jerzego, z podkreśleniem wpływów świata muzułmańskiego i zachodnioeuropejskiego zob. Vanderheyde 20I2. Autorka ogranicza się jednak przede wszystkim do sztuki malarskiej (freski i ikony) i pomija drobną wytwórczość (amulety, medaliony), uznając znajdujące się na takich przedmiotach wyobrażenia za zbyt schematyczne. 
męczeństwo, a nie waleczność (White 20I3: 2I-22), i tak też starano się go przedstawiać (Atanasov 200I: 57-58; Kolpakova 2013: I122-II23) ${ }^{8}$.Zdawano sobie jednakże sprawę z jego wojskowej przeszłości, gdyż znane są także równie wczesne przykłady nacechowanej militarnie ikonografii świętego. Można powołać się m.in. na krzyż procesyjny z VI w. znaleziony w Emesie (zachodnia Syria), obecnie w zbiorach Cabinet des médailles w Paryżu, na którym bez wątpienia (inskrypcja) uwieczniony został św. Jerzy w zbroi, z tarczą w lewej ręce (Atanasov 200I: IOI-IO2; 2002: 38-39; Walter 2003: I24, 27I). Według M. White tego rodzaju wizerunki były nawet bardziej popularne aniżeli ukazywanie go w „cywilnych” szatach męczennika. Mimo to hagiograficzny model przedstawiania Jerzego w ograniczonym stopniu powiązany był ze sferą wojskowości, tworząc jedynie kombinację z innymi jego atrybucjami i prerogatywami. Zachował on aktualność do X w., kiedy to święci przyjęli bardziej rozpoznawalną rolę militarną (White 2013: 25-26). Niekiedy uważa się, iż to walki Cesarstwa Wschodniego z Arabami i Słowianami, a na Zachodzie wojny z niewiernymi sprawiły, że do głosu dochodzić zaczął świecki wymiar św. Jerzego jako zbrojnego. Znajdowało to wyraz w tradycji ukazywania męczennika kapadockiego (obok innych świętych wojowników) w czasie bitwy jako niebiańskiego wspomożyciela jednej z walczących i uprzywilejowanych stron (Grygiel 2007: 93; Good 2009: 32-33; Grotowski 20II: 154-I55; Vanderheyde 2012: 206; Walter 2003: 133-I34; por. Juzepczuk 2018). W Bizancjum akcentowanie militarnych aspektów Jerzego miało też związek m.in. z propagowaniem wzorca świętego wojownika w kręgach wojskowych (Ovčarov 1991: I27; White 2013: 32nn). Jak stwierdziła M. White:

Przekształcenie garstki męczenników w imperialnych patronów wojskowych było procesem, który odzwierciedlał niektóre z ważnych zmian z końca IX i X w. Okres ten, naznaczony zarówno triumfami militarnymi, jak i konsolidacją w Kościele po ikonoklazmie, dał świadectwo bezprecedensowej fuzji militarnej i religijnej retoryki z obrazowością (White 2013: 92-93).

Nie sposób w niniejszym artykule zdać całościową relację ze złożonej problematyki dotyczącej sposobów ukazywania św. Jerzego oraz stylistycznego i ikonograficznego rozwoju jego wizerunków. Należy jednak, w nawiązaniu do militarnego wątku wyobrażania tego męczennika, odnieść się jeszcze do motywu walki z bestią. Ujmowano go w ramach dwóch podstawowych modeli: świętego jako wojownika pieszego albo jeźdźca, przy czym niemal zawsze z włócznią wbitą w wijącą się u dołu istotę, najczęściej przyjmującą postać zwierzęcą (fantastyczną lub realną). 8 Na temat początku kultu św. Jerzego i jego rozwoju zob. np. Pollems i989a; Walter i995;
Swastek i997. 
W nauce przyjął się pogląd, że w kręgu kultury bizantyńskiej najwcześniejsze dzieła artystyczne łączone ze św. Jerzym wojownikiem i wężobójcą nie mogą być datowane wcześniej niż na koniec IX i X w. (Lazarev 1953: 199-200; 1970: 72; zob. także Alpatov 1956: 2939). Tymczasem potwierdzono, że motyw ten jest znacznie starszy i sięgać mógł przynajmniej $\mathrm{v}$ w., za czym przemawiać miałaby przede wszystkim koptyjska tkanina z Achminu (Egipt) z końca IV-V w. Widać na niej zbrojnego przebijającego gadziopodobną istotę włócznią zakończoną krzyżem (ryc. 3). Z uwagi na imienne inskrypcje bardziej wiarygodne są jednak terakotowe ikonki odkryte w twierdzy Winica (Macedonia), przedstawiające św. Jerzego, św. Teodora i św. Krzysztofa jako wojowników pieszych pokonujących bestie (ryc. 2). Zabytki te datowane są na V-VI w. (Atanasov 2002: 37-38; 2010: 331-332; Kolpakova 2013: II23) ${ }^{10}$. Równie wczesną genezę najprawdopodobniej mają również wizerunki św. Jerzego jadącego konno i walczącego z wężem, choć nie zawsze są one już tak bezsporne (Atanasov 200I: I8I-I89; 2002: 39-4I). Do ciekawszych ujęć należy malowidło z początku viI w., pochodzące z kościoła nr 3 w Mavrucan (Kapadocja, Turcja). Przedstawiono na nim św. Jerzego i św. Teodora konno we wspólnym wysiłku atakujących węża owiniętego wokół drzewa (ryc. 4). Taki sposób obrazowania gada, któremu przypisywana jest orientalna (zapewne sasanidzka) proweniencja, nie jest znany z późniejszej ikonografii świętych jeźdźców (Walter 2003: 125, ryc. 27; Pancaroğlu 2004: 154; Kolpakova 2013: 1123).

Tradycja powstawania wszelkich militarnych wyobrażeń św. Jerzego kontynuowana była w VIII-IX w. na niektórych peryferyjnych obszarach Bizancjum, takich jak Egipt, Bliski Wschód, Zakaukazie, Krym, południowe Włochy, a także w Europie Zachodniej, pozostających poza strefą oddziaływania ikonoklazmu. Po ustaniu

9 Panuje też przekonanie, że w tradycji zachodnioeuropejskiej motyw walki św. Jerzego ze smokiem pojawił się dopiero w XII w. (Pollems 1989b: 1274; Daranowska-Łukaszewska, Jacniacka 1997: 1226; Arutyunyan 2009: 165-166; Hahn 2001: 77), co jednak niekoniecznie musiało odpowiadać rzeczywistości. W każdym razie kult tego świętego na Zachodzie w średniowieczu był mocno związany z etosem rycerskim (zob. MacGregor 2004), a czasy wypraw krzyżowych zaznaczyły się pojawieniem się znacznie większej liczby jego przedstawień (Cormack, Mihalarias 1984: 132-133). Według V. Agrigoroaei nie był wówczas potrzebny święty-męczennik, ale taki, który pozwalałby uśmiercać saraceńskich niewiernych. Kryterium to spełniał św. Jerzy, a do takiego wyboru doszło najpewniej w początkach XII w. (Agrigoroaei 20II: 93-94). Patronat nad rycerstwem w XIII w. święty ten w znacznej mierze zawdzięcza Jakubowi de Voragine († 1298 ) i jego Ztotej Legendzie, w której mowa jest o zgładzeniu przez niego smoka (Le Goff 2020: I28).

10 Metryka tych zabytków nie jest jasno określona i mieści się w przedziale między IV a IX w. W świetle przeprowadzonej niedawno analizy pochodzą one z VI w., a do ich zniszczenia doszło zapewne w czasach Leona III (717-74I). Wówczas to zapoczątkowany został ikonoklazm, a terytorium dzisiejszej Macedonii w 733 r. ostatecznie poddane zostało władzy Konstantynopola (Ǵorǵievski 2012: 2015; zob. także Walter 2003: I25). 


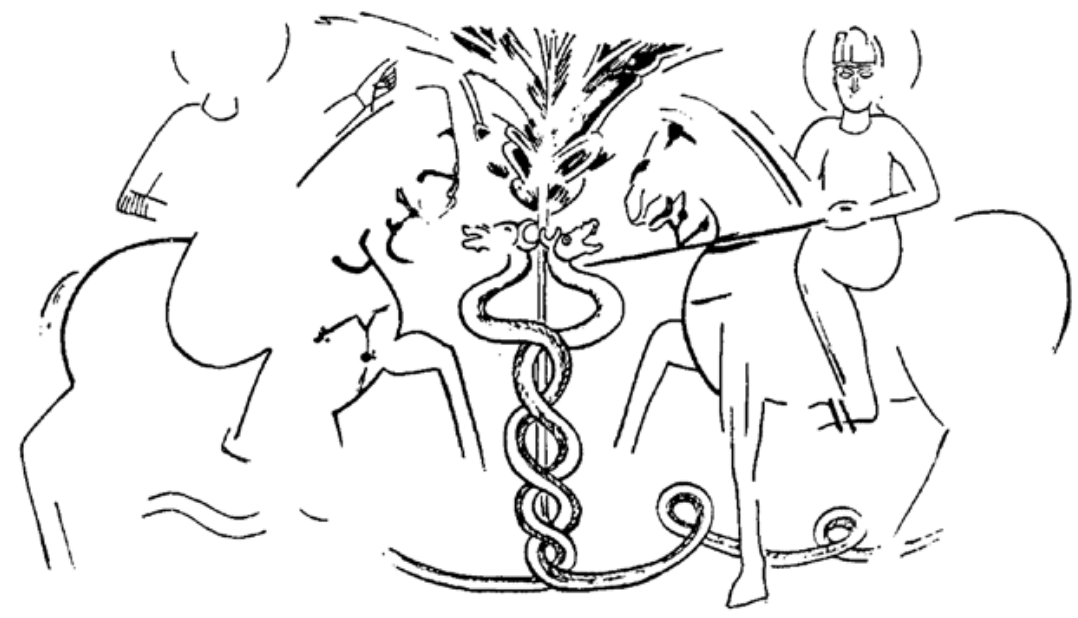

Ryc. 4. Malowidło ze św. Jerzym i św. Teodorem z kościoła nr 3 w Mavrucan (Kapadocja, Turcja), początek viı w. (Walter 20I3: ryc. 27). Oprac. T. Kurasiński.

obrazoburstwa, za sprawą tychże wizerunków doszło do odrodzenia wojskowej ikonografii kapadockiego świętego, a do najpopularniejszych jego realizacji należał „wojownik-piechur” i „jeździec-wężobójca" "11. Ten ostatni motyw stał się popularny zwłaszcza na obszarach wschodnio-prowincjonalnych oraz kulturowo pozostających pod wpływem bizantyńskim (Atanasov 2001: 104-107, 189-207; 2002: 42-49; 2010: 336-337, 340; Immerzeel 2004; Pancaroğlu 2004; Snelders, Jeudy 2006; Reginskaya 20ı: 2I). W samym zaś „konstantynopolitańskim” Bizancjum okresu poikonoklastycznego obraz św. Jerzego zabijającego węża był rzadkością, a to ze względu na brak jego akceptacji ze strony metropolitalnego duchowieństwa. Wyobrażano go głównie jako wojownika pieszego. Dopiero od schyłku XII-XIII w. i odebraniu w I26I r. z rąk krzyżowców stolicy (okres Paleologów) zaczął oficjalnie upowszechniać się wizerunek jeździecki, także w scenach walki z gadzią bestią (Atanasov 200I: 2II-2I4; Kolpakova 2003: II24nn; zob. także Reginskaya 20IO: I7nn). Na rzadkość takiej kreacji św. Jerzego, zwłaszcza jako wężobójcy, wskazuje bizantyński materiał sfragistyczny z X-XII w. (Stepanenko 2019; 2020).

11 Odrodził się także motyw świętego kapadockiego zmagającego się z wężem pieszo, choć jego obecność w sztuce użytkowej bizantyńskiego kręgu kulturowego zaznacza się tylko w ograniczonym zakresie (zob. ołowiane ikonki z południowej Dobrudży pochodzące $\mathrm{z}$ końca $\mathrm{X}$ - początku XI w. (niektórzy badacze datują je jednak później - na drugą połowę XII - początek XIII w.); zob. Totev 2000). Przyczynę tego upatruje się w większej sile oddziaływania Jerzego w roli wojownika konnego pokonującego bestię - poskromiciela zła (Atanasov 2010: 337-34I). 


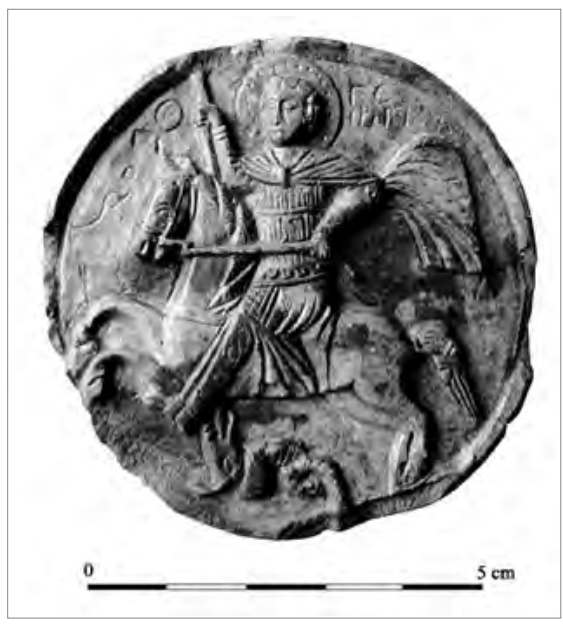

Ryc.5. Kamienna ikonka ze św. Jerzym z Kijowa (Starokiyevskaya gora, przy tzw. Zachodnim Pałacu), koniec XII - I. połowa XIII w. (wg Arkhipova 2015: ryc. 5:6). Oprac. T. Kurasiński.

Z porównywalną sytuacją mamy do czynienia na Rusi w okresie przedmongolskim. Zgodnie ze staroruską redakcją żywota św. Jerzego był on postrzegany przede wszystkim jako męczennik, głosiciel doktryny chrześcijańskiej (Vereshchagina 20I9: 352). Na ówczesnych pieczęciach ruskich święty jeździec, w tym Jerzy, ukazywany był dość sporadycznie (Stepanenko 2000; Chukova 2006: 52). Podobnie w przypadku kamiennych ikonek, na których przed XIII w. niemal nie spotyka się wyobrażeń św. Jerzego w roli jeźdźca zabijającego węża (ryc. 5) (zob. Nikolayeva 1983; Arkhipova 2015). Mimo iż na tego rodzaju wyrobach jego wizerunki ustępują jedynie św. Mikołajowi (Porfiridov 1972: 203-204). Najwcześniejsze (XI-XII w.) wizerunki świętych wojowników konnych w walce z wężem na Rusi pojawiają się na kamiennych reliefach (ryc. 6) (Zhyshkovych 1999: 86-87; Stepanenko 2000: 108; Atanasov 200I: 208; Moskal' 2020: 222-223, 226). Podobnie jak w Konstantynopolu, sporadyczne wykorzystywanie motywu wężobójstwa miało zapewne związek ze sprzeciwem ze strony oficjalnej myśli kościelnej wobec cieszącej się popularnością literatury apokryficznej o cudach i czynach świętych, zawierającej wątki o zmaganiach wojowników z wężem lub diabłem, także św. Jerzego (Stangé-Zhirovova 1992: 327-328; Propp 2002: 98; Moskal' 2020: 221 I2 . Dopiero po najeździe mongolskim motyw ten nabrał rozmachu, stając się jednym z ulubionych tematów w sztuce staroruskiej. Okoliczności polityczne wymagały bowiem specjalnej ochrony sakralnej (Moskal' 2020: 223nn).

Wszystko to pokazuje, jak ważnymi w kultywowaniu męczennika kapadockiego znaleziskami były rozpatrywane zawieszki.

12 Wskazywane są trzy formy czy tendencje kształtowania się kultu św. Jerzego: I. oficjalna (kościelna); 2. popularna (ludowa) o silnym pogańskim podłożu (legendy, pieśni, bajki, obrzędy ludowe); 3. pośrednia. Ta ostatnia obejmuje pojemny obszar pomiędzy czysto kościelnym postrzeganiem świętego a pogańską jego percepcją. Wypełniają go takie elementy, jak jego kult militarny, literatura apokryficzna, rytuały i wierzenia związane z jego imieniem i odbywające się w środowisku kościelnym, ale zawierające niektóre elementy niechrześcijańskie itp. (szerzej Stangé-Zhirovova 1992; o ludowych wierzeniach i obrzędach związanych z dniem św. Jerzego zob. Jaszczewska 20ı)). 
Wydaje się, że sceny walki z wężem w ikonografii świętego kapadockiego należą do tradycji czysto przedstawieniowej, pozbawionej jakiejkolwiek kanwy literackiej. Brak jest źródeł narracyjnych pochodzących sprzed okresu ikonoklastycznego, jak również późniejszych ${ }^{13}$, uzasadniających ideologiczno-artystyczną wymowę takich wyobrażeń. Postać św. Jerzego w charakterze wojownika i wężobójcy pojawiła się zapewne pod wpływem biblijnych tekstów, gdyż zarówno w Starym, jak i w Nowym Testamencie obraz węża jest silnie powiązany z ciemnymi mocami szatańskimi (szczególne znaczenie mają nawiązania do nowotestamentowej Apokalipsy). Przypuszczalnie mamy do czynienia ze swoistą alegorią religijnych starć, toczonych przez Kościół z poganami, heretykami i barbarzyńcami, z którymi owe moce mogły być utożsamiane. Artystycznym wyrazem tych idei, a zarazem źródłem zapożyczeń dla wizerunków Jerzego, mogły być przedstawienia cesarskie Konstantyna Wielkiego i jego następców, ukazywanych jako wojownicy-wężobójcy, zarówno konni, jak i spieszeni ${ }^{14}$. Istotne są również wczesne wyobrażenia Chrystusa i Michała Archanioła, którzy odziani w stroje wojskowe zwyciężają węża, depcząc go. Oznaczałoby to, że tak jak Bóg walczy z szatanem, tak chrześcijańscy cesarze toczą bitwy, pokonując jego ziemskie pogańsko-heretyckie inkarnacje, uwidaczniane pod gadzią postacią (na ten temat szeroko Atanasov 200I: 176-178; 2002: 42, 48; 2010: 332-336).

Dochodzimy tu do sygnalizowanego już wątku mitycznej walki władcy, bóstwa bądź herosa z demoniczną istotą, kulturowo mocno zakorzenionego w tradycji indoeuropejskiej i bliskowschodnich cywilizacjach ${ }^{15}$. W chrześcijańskiej sztuce wschodniej, szczególnie bizantyńskiej, znalazł on artystyczny wyraz w postaci wojskowego świętego, który pieszo bądź konno odnosi zwycięstwo nad gadziopodobnym monstrum lub pogańskim cesarzem, swym ciemiężycielem (zob. np. Walter 2003; Grotowski 20II; White 2013). Przykładem są rozpatrywane zawieszki

13 Jak dotąd nie jest znany żaden pisemny zabytek z XI-XII w., który zawierałby wzmiankę o bezpośredniej walce św. Jerzego z wężem-smokiem. Nawet we wczesnych wersjach cudu ze smokiem i księżniczką święty razi potwora nie bronią, ale modlitwą i znakiem krzyża (Atanasov 2001: 175; 2010: 330).

14 Stawiana jest nawet hipoteza, zgodnie z którą ikonograficzny typ św. Jerzego jako wojownika-żmijobójcy ukształtował się pod wpływem wizerunków egipskiego boga Seta, przebijającego włócznią węża (Karlova 2020).

15 One or more myths about a god or hero killing a dragon or other reptilian adversary, usually just called 'snake, serpent', is found in a vast number of cultures around the world; it may be a quasi-universal (Watkins 1995: 297). Smok zawsze chętnie stawiany był w roli konwencjonalnego i sugestywnego adwersarza (m.in. Gierszewska 20I2; Mianecki 20I2; Sikorski 2015; Honneger 2019). W pogańskiej religijności Słowian archetypiczne kompetencje herosa-smokobójcy przejawiał Świętowit, który nocą wyprawiać się miał konno przeciw sitom chaosu (Szczepanik 2015). 
z wizerunkiem świętego jeźdźca utożsamianego z kapadockim męczennikiem, na których nadal pobrzmiewa motyw odwiecznej bitwy. Powstały one zgodnie z kanonami ikonografii chrześcijańskiej, dla ukazania zarówno mocy Bożej, jak i potęgi świętego. Jednocześnie ich treść sięga głębszych pokładów znaczeniowych, związanych z odwzorowaniem kosmicznego pojedynku pomiędzy pierwotnymi siłami identyfikowanymi z chaosem i destrukcją a dążącymi do zaprowadzenia ładu społeczno-cywilizacyjnego. Bez tych odwiecznych i cyklicznie powtarzających się zmagań, rytualnie uaktualnianych, niemożliwa byłaby odnowa życia (zob. Watkins 1995: 299-300). Tę archetypową wykładnię walki przeciwstawnych sił w wielu aspektach przejął obraz św. Jerzego triumfującego nad złem i ciemnością (zob. Mikhaylova 2003: 18I; Shtepanovskaya 2009). Unieszkodliwienie węża przez zadanie ciosu włócznią oznaczało dokonanie aktu kreacji, przejście od formy ukrytej i amorficznej do jawnej i ukształtowanej (Moskal' 2020: 22I). Jeździec stał się inkarnacją boskich sił natury, a swą funkcję militarną wypełniał jako dawca płodności, pomyślności i światła. Mitologiczna podstawa jego wyczynu w wizerunkach św. Jerzego-wężobójcy została zatem przekształcona i wyrażona w duchu chrześcijańskim na obraz prawosławnego rozumienia ożywczego Ducha i życiodajnej Trójcy Świętej (por. Nekrasova 2009) ${ }^{16}$. Na Rusi Kijowskiej motyw św. Jerzego pokonującego węża uosabiał ideę zwycięstwa wiary chrześcijańskiej nad pogaństwem (Vereshchagina 2019: 357) ${ }^{17}$.

Istotne znaczenie w prezentowanych przedstawieniach ma także koń. Jako istota bliska bogom lokuje się wysoko w mitologicznych przekazach rozmaitych

16 Sięgający odległej przeszłości motyw walki pomiędzy mitycznym potworem lub smokiem a jego pogromcą w nieunikniony sposób musiał podlegać zmianom i reinterpretacji. Również legenda o św. Jerzym i smoku okazywała swą otwartość znaczeniową. At different times, and in different images, it can be seen as symbolising the subjugation of pagan beliefs by the Christian church, the suppression of heretical movements, the battle over Christian sexual morals and the ultimate victory of Christ over the devil (Morgan 2006: 58-59; zob. także Moskal' 2020). Starano się nawet dostrzec w owej legendzie przekaz wpisujący się w alchemiczną symbolikę (Maré 2004).

17 Podejmując próbę konceptualizacji wszelkiego rodzaju więzi i afiliacji religijno-strukturalnych, trzeba mieć jednakże na uwadze zakłócenia powyższego obrazu prowadzące do reorientacji, niekiedy też inwersji, w ukazywaniu się prerogatyw i przymiotów niektórych świętych. Podkreślił to C. Deptuła: [c] i sami święci przejawiają w pewnych przypadkach cechy gromowtadcy, winnych - cechy wielkiego węża. Przyporządkowanie poszczególnych herosów chrześcijańskich tradycyjnym sferom sakralnym - niebiańskiej i tellurycznej - któci się czasem z sugestiami poddawanymi przez hagiografie i formy kultu. Ponadto święci mieszaja sięze soba w swych atrybutach i zachowaniach, zmieniaja się rolami, zastępuja wzajemnie w relacjach $z$ ludźmi i przyrodą, w funkcjach i patronatach (Deptuła 2003: 104). Istoty z chrześcijańskiego panteonu mogą również przyczyniać się do dezintegracji i nieszczęścia, aczkolwiek [n] a wyższym poziomie destrukcja ta jest jednak interpretowana jako podtrzymanie porzadku i postrzegana w kategoriach boskiej kary (Zając 2003: 93). 


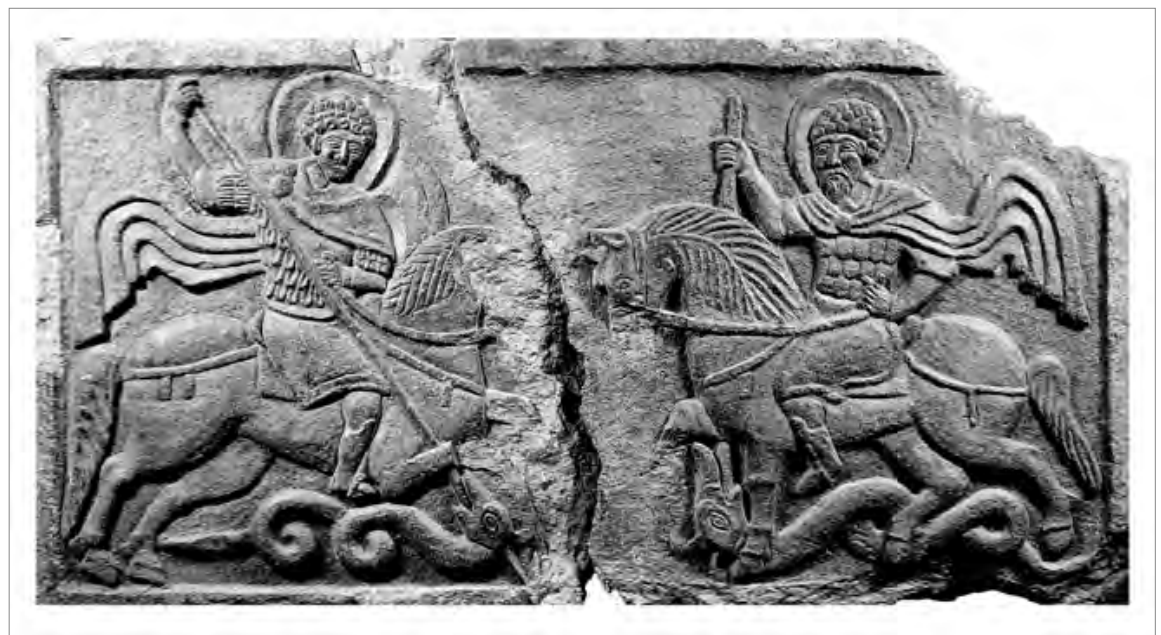

Ryc.6. Kamienny relief ze św. Jerzym i św. Teodorem z Kijowa (monaster św. Michała Archanioła o Złotych Kopułach), koniec XI - początek XII w. (wg Zhyshkovych I999: ryc. na s. 84). Oprac. T. Kurasiński.

kultur, ma również utrwaloną pozycję w symbolice chrześcijańskiej, m.in. alegorycznie ukazuje szybkość zmierzania ludzkiego życia ku celom ostatecznym (Lurker 1989: 90-92; Forstner 1990: 272-275). Z jednej strony symbolizowat militarne męstwo i władczą godność, z drugiej zaś był zwierzęciem o bardzo niejednoznacznych konotacjach i skojarzeniach. W tradycji wielu ludów zachowały się legendy o koniach - cudownych pomocnikach, niosących jeźdźców do miejsc uświęconych i na każdą odległość, ale też wskazujących na silne ich zespolenie z ziemią, ze światem tellurycznym. Nie tylko ułatwiały one zejście do podziemi, ale także, o ile wprost nie kontrolowały sił chtonicznych, zdolne były do uaktywnienia witalnej energii odtwarzania i wzrostu (Mukhin 2009: 22I-222; Gapski 20I4: 87).

W bizantyńskim systemie znaczeń i wartości konia uznawano za zwierzę prestiżowe i paradne, wykazujące powiązania z cesarskim triumfem i statusem. $Z$ tego też względu stanowił szczególnie cenny dar. Był też jednym z nielicznych reprezentantów fauny uznawanym za przedstawiciela Boga na ziemi, co sprawiało, że nadawano mu wymiar nad-zwierzęcy (dimension supra-animale) (Drocourt 2004: 79; Vanderheyde 20012: 201-202).

Koń, jako istota hybrydalna, nacechowana elementami pogańskiej i chrześcijańskiej symboliki, ukazywał średniowiecznemu człowiekowi całe spektrum pojmowania związanej z nim osoby. Zwierzę to wręcz utożsamiano z jeźdźcem. Heros na koniu uosabiał niejako ów stan pogranicza, zwracając się zarówno ku pogańskiej przeszłości, jak i chrześcijańskiej teraźniejszości. Było to możliwe w warunkach synkretyzmu religijnego panującego na Rusi, zwłaszcza na ziemi nowogrodzkiej, 
co znajdowało swoje odzwierciedlenie w twórczości artystycznej (Mukhin 2009: 222-223). W powszechnej świadomości święty jeździec stał się zatem bohaterem nowego typu, który walczy z mrocznymi siłami zła i jest pośrednikiem między światem ziemskim a niebiańskim (Moskal' 2020: 222). Stąd św. Jerzy reprezentował te funkcje i cechy, które odpowiadały także tradycyjnemu oglądowi świata. To, że jako jeździec ujarzmił i zwyciężył węża - istotę do niedawna czczoną, musiało urzekać chrześcijańskich neofitów bardziej niż jego udręczenie i męczeńska śmierć (Mukhin 2009: 223). Nieprzypadkowo w sposobie przedstawiania świętego pokonującego wroga ucieleśniał się ludowy ideał męstwa, brawury i sił witalnych (Usikova 2015: 135, 137, 138; zob. także Alpatov 1956: 297).

Siła świętego tkwi również w przedmiotach i atrybutach, którymi dysponuje. Oprócz konia jest to oręż - w naszym przypadku włócznia, będąca narzędziem triumfu nad nieczystymi siłami, co niekiedy podkreślane było zwieńczeniem w postaci krzyża (crux hastata). Ten ikonograficzny szczegół w przedstawianiu broni drzewcowej w rękach świętych wojowników, także św. Jerzego, utrzymywał się w sakralnej sztuce bizantyńskich środowisk prowincjonalnych do $\mathrm{X}$ w. (Grotowski 20II: 384-390).

Grot w tych przedstawieniach jest skierowany niemal zawsze ku dołowi - w strefę uznawaną za wysoce pejoratywną. Zgodnie bowiem z przestrzennym waloryzowaniem świata wyznaczonym przez mitologicznie uzasadniony ${ }^{18}$ porządek wertykalny („góra” - „dół”), temu co położone najniżej nadawany jest wymiar negatywny. To tam swoje lokum ma zło lub jego uosobienie - diabeł i inne demony; jest to też kraina zmarłych (zob. Kurasiński 20I4: 174-175). W średniowieczu dualny charakter wyobrażeń wyrażał się w parach przeciwieństw, rozmieszczonych wzdłuż pionowej osi: niebiańskie przeciwstawiało się ziemskiemu. Pojęcie "góry” wiązało się ze szlachetnością, czystością, dobrem, podczas gdy „dół” nosił znamiona nieczystości i zła. Nieprzystawalność materii i ducha, ciała i duszy również nosiło w sobie przeciwstawienie „dołu” $i$ „góry”. Pojęcia przestrzenne były zatem nierozerwalnie złączone z religijno-moralnymi (Guriewicz 1976: 74, 76, 80).

Rozpatrując treści ikonograficzne i znaczeniowe omawianych zawieszek, należy także zadać pytanie o właścicieli/dysponentów tychże przedmiotów, a w dalszej kolejności o powody ich noszenia. Obydwie te kwestie - kto? i dlaczego? - rysują się dość enigmatycznie. Odwzorowanie wojownika w scenie walki wskazywałoby na „męski” charakter omawianych zawieszek i ich przynależność do sfery związanej z wojskowością. W literaturze akcentowane jest duże znaczenie kultu świętych wojowników, szczególnie św. Jerzego, w ruskim środowisku drużynniczym.

18 Mit jako element wzorcowy stanowi źródło umożliwiające klasyfikację przestrzennych komponentów, nadawanie im sensu i ustalenie wzajemnych powiązań (Tuan 1987: I2I). 


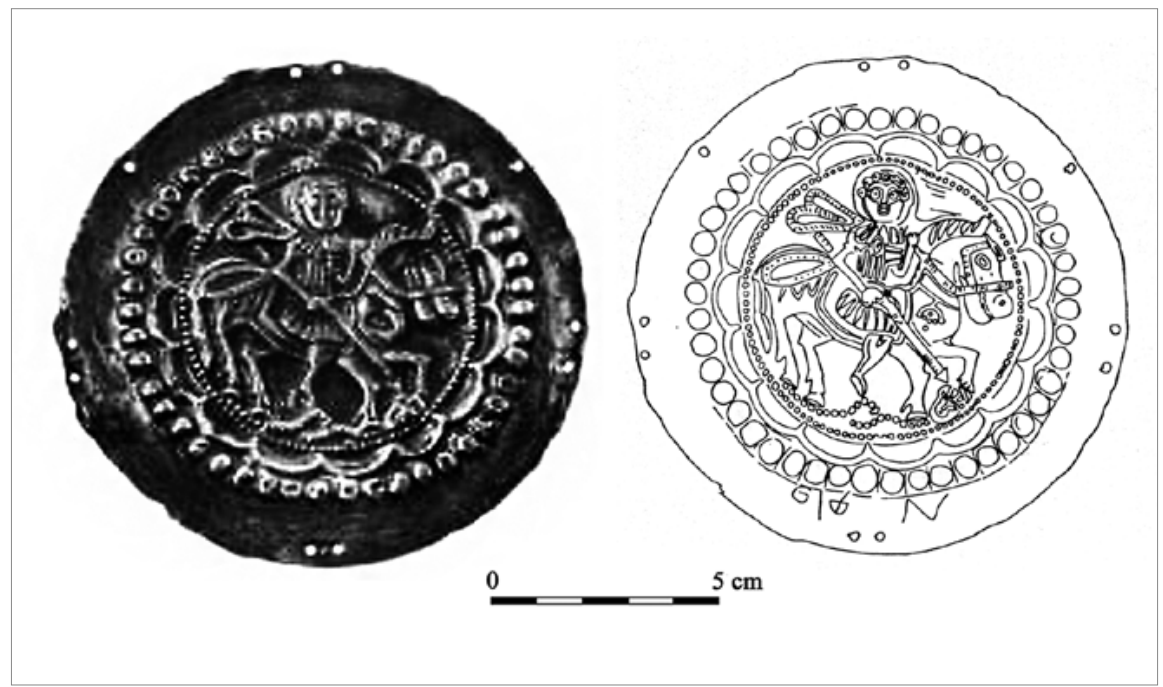

Ryc.7. Zapinki tarczowate ze świętymi jeźdźcami z awarskich cmentarzysk na terenie Panonii. I - Keszthely-Fenékpuszta-Dobogó; 2 - Keszthely-Fenékpuszta-Horreum; 3 - Nagyharsány (wg Á. Bollók 20I4: ryc. I:I-2, 5:I). Oprac. T. Kurasiński.

Będąc patronami wojskowymi i książęcymi mieli być oni przykładem do naśladowania, podtrzymując gotowość bojową do walki z wrogiem, a zarazem roztaczać opiekę w działaniach wojennych (np. Myts'ko 1998: 30; Mikhaylova 2003; Pivovarov 20II: 392; Ters'kyy 2016: 62) ${ }^{19}$. Możliwe więc, że istniało zapotrzebowanie na zawieszki ze świętymi jeźdźcami wśród drużynników.

Jak już jednak wiemy, zawieszki te odkrywane są w pochówkach kobiecych, gdzie stanowiły element kolii. Z taką sytuacją zetknęliśmy się w Dołubowie ${ }^{20}$ i Święcku Strumianach. Funkcję tę pełniły one także na innych cmentarzyskach. Przykładowo, w grobach z łotewskiej nekropolii w Kristapin,i, Aglonas novads, uzupełniały one kolie, w skład których wchodziły inne dewocjonalia (krzyżyki, medalion z Matką Boską Orantką), paciorki szklane, dzwoneczki i ząb zwierzęcy (Kuniga 2000: 46, II8, I33, I46, ryc. IX:26, XXI:6a, 7a-b). Również na terenach

19 Na marginesie należy dopowiedzieć, że w opinii R. Brūzisa późnośredniowieczne pochówki męskie z włóczniami i ostrogami (XIV-XV w.) pochodzące z Łotwy mogą świadczyć o manifestującym się w materiale archeologicznym kulcie św. Jerzego. Taki zestaw wyposażenia pośmiertnego, wskazujący na wysoki status zmarłych, nawiązywał bowiem do najważniejszego patrona duchowego tamtejszych elit. Zwolennicy kultu Jerzego, zdobywającego popularność w okresie rozkwitu ideologii rycerskiej, liczyli na jego przychylność i ochronę w działaniach wojennych (Brūzis 2017).

20 Tu przypuszczalnie, gdyż szczątki ludzkie się nie zachowały (Dzik 2015: 197). 


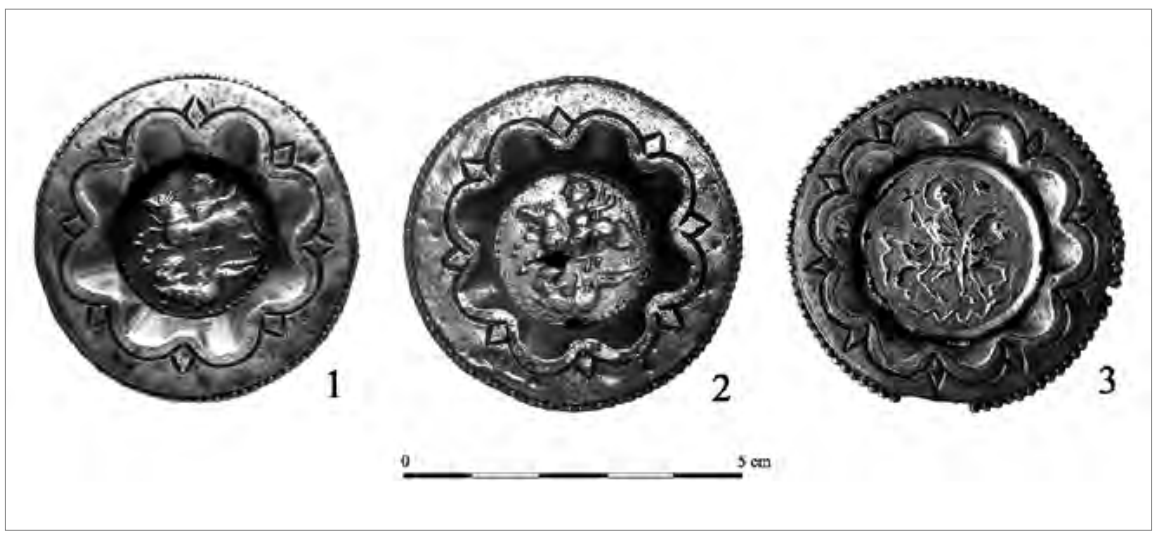

Ryc. 8. Falera z Chrystusem (?) z grobu komorowego w Hüfingen (Niemcy) (wg Quast 2002: ryc. I:I; 2009, ryc. 3:I). Oprac. T. Kurasiński.

ruskich to kobiety chowane były z różnego rodzaju zawieszkami przypisywanymi św. Jerzemu. Najczęściej wchodziły one w skład naszyjników lub występowały w charakterze kolczyków (Sedova 2006: 245-246).

Warto w tym miejscu odwołać się do wyrobów z okresu merowińskiego ze scenami figuralnymi, wśród których znajdują się elementy rzędu końskiego - falery z wizerunkami wojowników, w tym z jeźdźcami (ryc. 8). Zabytki te znajdowane przede wszystkim w południowo-zachodnich Niemczech (Alemania) docierały tam w krótkim okresie czasu około $600 \mathrm{r}$. z Włoch, niektóre były miejscową imitacją (Quast 2009). Co ciekawe, tego rodzaju wizerunki - w znaczeniu świętych wojowników ${ }^{21}$ - odegrały jedynie epizodyczną rolę w ówczesnym świecie mężczyzn. Tamtejsi zbrojni bardzo szybko zarzucili zwyczaj używania takich wizerunków, zaś z początkiem viI w. na północ od Alp motyw ten, łącznie z rozpatrywanym tu typem „świętego jeźdźca”, zaczął upowszechniać się na elementach stroju kobiecego, odkrywanych głównie w grobach. D. Quast tłumaczy to w ten sposób, że być może zbrojni nie pojmowali symbolicznego ich przesłania lub tak naturalistyczne wyobrażenia okazały nikłą skuteczność jako nośniki tożsamościowej komunikacji grupowej dla ludzi parających się rzemiosłem wojennym. Nie znaczy to, że - w przeciwieństwie do kobiet - mężczyźni trwali przy wierzeniach przedchrześcijańskich. Do głosu dochodziły tu raczej męsko-damskie różnice mentalne tamtych czasów (Quast 2009: 339).

$21 \mathrm{~W}$ ocenie G. Fingerlina na falerach z grobu komorowego odkrytego w Hüfingen, SchwarzwaldBaar-Kreis, z wizerunkiem konnych wojowników (jeden z nich, przypuszczalnie z nimbem, mierzy włócznią w węża lub robakowatą istotę o ludzkiej twarzy) ukazany został Chrystus (Fingerlin 2008: 68; 2012: 18). 
Niewykluczone, że podobne czynniki i okoliczności zachodziły w przypadku zawieszek przypisywanych św. Jerzemu, choć inne realia kulturowe, a także niewielka baza źródłowa pozwala wypowiadać się w tej kwestii jedynie hipotetycznie.

Wobec funeralnego kontekstu ich deponowania pojawia się problem wyznaniowej przynależności osób z nimi pochowanych. Wiąże się to bezpośrednio z pytaniem o przyczyny noszenia rozpatrywanych zawieszek. Być może obecność ich w grobach była wynikiem działalności chrystianizacyjnej, co przemawiałoby za przynależnością zmarłego do wiary chrześcijańskiej (zob. Żółkowska 20ı16: 274). G. Atanasov w odniesieniu do analogicznej srebrnej zawieszki (koniec X w.) z twierdzy w miejscowości Car Asen w pobliżu Silistry (Bułgaria) stwierdził, iż ukazana na niej idea walki z siłami diabelskimi, rozpoczęta przez starotestamentowych proroków i kontynuowana przez świętych wojowników, była podejmowana przez każdego chrześcijanina, a zwtaszcza przez tych, którzy nosili takie medaliony (Atanasov 200r: 193-194).Z kolei M.V.Sedova w odniesieniu do okazów pochodzących z kurhanów odkrytych na terenie północno-wschodniej Rusi uznała, że były one postrzegane jako chrześcijańskie amulety ochronne. Sama zaś ich obecność w pochówkach kobiecych świadczy o większej skłonności kobiet do akceptacji nowej wiary (Sedova 2006: 246).

W dyskusji nad znaczeniem dewocjonaliów w wyposażeniu pośmiertnym często wyrażane są jednak wątpliwości odnośnie do przydatności tej kategorii znalezisk jako wyznaczników formacji religijnej zmarłych (zob. np. Staecker 1997: 444-445; Buko 2016: 46). Podkreślane jest współwystępowanie w koliach krzyżyków z innymi zawieszkami o funkcji amuletów (np. zęby zwierzęce, muszle), obserwowane na wczesnośredniowiecznych cmentarzyskach z terenu Polski, zwłaszcza wschodniej. W zjawisku tym dostrzega się przejaw synkretyzmu religijnego, uchwytnego w ówczesnej obrzędowości pogrzebowej (Kóčka-Krenz 2002: 161; zob. także Żółkowska 2010: 245, 247). Zawieszkom w formie krzyża noszonym w XI-XIII w. na terytorium Łotwy odmawiane są związki z chrześcijaństwem. Włącza się je tam w poczet pogańskich amuletów (Radiņ’š 2007: 297). Także wspomniane falery, niewątpliwie przedmioty o znaczeniu elitarnym, skupiały w sobie treści pogańskie i chrześcijańskie. Trudno byłoby zatem doszukiwać się w nich wyznaczników religijnej konfesji zmarłego (Quast 2002: 275-276), aczkolwiek dostrzega się w nich także koneksje z wiarą chrześcijańską (Fingerlin 2012: 19-20).

Rozpatrując semantyczny przekaz zawieszek z przedstawieniem świętych jeźdźców, warto także uwzględnić ustalenia dotyczące innej grupy znalezisk. Mamy na myśli zapinki tarczowate (niem. Scheibenfibeln, ang. box brooches) pochodzące $\mathrm{z}$ cmentarzyskach awarskich na terenie Basenu Karpackiego. Wśród nich uwagę zwracają okazy z centralnie ukazanym jeźdźcem trzymającym włócznię w konnej walce z monstrum przypominającym węża lub smoka. Podobnie jak rozpatrywane 
zawieszki, również te przedmioty trafiały do grobów, w których chowano kobiety (Keszthely-Fenékpuszta-Dobogó, Zala megye, grób nr I885/V; Nagyharsány, Baranya megye, grób nr 60), a w jednym przypadku był to pochówek dziecięcy (Keszthely-Fenékpuszta-Horreum, Zala megye, grób nr I2) (ryc. 7). W klasyfikacji É. Garam zapinki te tworzą jedną z pododmian grupy I (Fibeln mit der Darstellung von Reiterfiguren) (Garam 1993: 99-IOI, ryc. I:I-3), której okazy pozostawały w użyciu od końca VI do początku VII w. (Garam 1993: II9, I3I). Pod względem ikonograficznym szczególnie wyróżnia się zapinka z Nagyharsány. Widoczny na niej jeździec ma głowę otoczoną nimbem i dźga wijącego się u dołu węża włócznią zakończoną krzyżem (Papp 1963: 13I-I32, tabl. XI:5, XXI) ${ }^{22}$. Według niektórych zapatrywań chodzi o wizerunek św. Jerzego walczącego ze smokiem (Vaday 2013: 2) ${ }^{23}$, aczkolwiek sugerowana jest też postać Chrystusa (Tóth 1999: 172; 2005: I84). Stąd niektórzy badacze starają się przekonać, że zapinki te świadczą o chrześcijańskiej wierze osób je noszących (Tóth 1999: 172).

Szeroko w kwestii omawianej grupy zapinek wypowiedział się Á. Bollók, który wyodrębnił dwa typy ikonograficzne: schrystianizowane przedstawienia politeistyczne („pogańskie”) i przedstawienia stricte chrześcijańskie. Pierwszy reprezentowany jest przez okazy z Keszthely-Fenékpuszta ukazujące archaizujące przedstawienie Bellerofona $\mathrm{z}$ Chimerą ${ }^{24}$, natomiast $\mathrm{w}$ drugim znalazł się egzemplarz z Nagyharsány z uwidocznionym na nim anonimowym świętym jeźdźcem (Bollók 20I4: 264-265, 271-272). Brak inskrypcji pozostawia problem identyfikacji konnego wizerunku otwartym. W literaturze nadal trwa dyskusja nad ikonograficzno-symboliczną wymową zapinek tarczowatych z figuralnym zdobnictwem, w tym także okazów z przedstawieniami jeźdźców. Przedmiotem sporu są także proweniencja i funkcja tego rodzaju znalezisk. Przykładowo, É. Garam przyjęła, że najwcześniejsze formy (w tym omawiane egzemplarze) pochodziły z Sirmium (Garam 1993: 13I). Z kolei E. Tóth uważa, że były to przedmioty wykonywane lokalnie, dające świadectwo śródziemnomorskich powiązań (Tóth 1999: 172). Część badaczy, uznając ich bizantyńskie pochodzenie, przypisała im funkcję pojemników na wtórne relikwie (Sekundärreliquienbehälter), a to głównie z uwagi na swą zawartość, np. wosk pszczeli (być może pochodzący z miejsc świętych), którego

22 Nimb ma charakteryzować wyobrażoną postać jako świętego jeźdźca, który niszczy swoich wrogów i w ten sposób odpiera zło. To sprawiało, że był to znak apotropaiczny (Glaser 2002: 147-I 48).

23 Wcześniej wskazywał na to L. Barkóczi, który z męczennikiem kapadockim powiązał także okazy z Keszthely-Fenékpuszta (Barkóczi 1968: 282, 289, tabl. LXI:2, LXX:7). Z kolei F. Glaser bardziej ogólnie w wizerunkach zamieszczonych na tych zabytkach upatrywał świętych jeźdźców (Glaser 2002: 147-148).

24 Taką opcję przyjął też E. Tóth (2005: 183-186; 2013: 208-209). 
obecność potwierdzana jest wewnątrz zapinek tarczowatych (Daim 2002: II5, II9; Vida 2002: 184; sceptycznie Vaday 2013: 3$)^{25}$.

W świetle dotychczasowych ustaleń można stwierdzić, że ikonograficzny program omawianych zawieszek stanowi schrystianizowaną wizualizację i aktualizację motywu będącego archetypicznym odwzorowaniem boskiej konfrontacji ze złem, którego istota sprowadza się do zaprowadzenia ładu i zapanowania nad chaosem. Warto przy tym pamiętać, iż nie był to jedyny nośnik obrazowy/ikonograficzny ukazujący kapadockiego męczennika, czemu także dano wyraz w niniejszej pracy. Z drugiej zaś strony świętych jeźdźców walczących z bestią było znacznie więcej (np. Michał Archanioł, Demetriusz z Tesaloniki, Syzyniusz Antiocheński, Teodor Stratilates, Teodor Tyron i inni - zob. Walter 2003). Pokazuje to, że idea ufundowana na scenariuszu mitycznej drakomachii realizowana była w rozmaity sposób, zaś medalionowate zawieszki, z dużym prawdopodobieństwem przypisywane św. Jerzemu, były tylko jednym ze sposobów jej ukazania.

Wymowa religijno-symboliczna i mitologiczna wskazuje na synkretyczny charakter zakodowanych w nich treści. Przedmioty te jako dewocjonalia mogły być świadectwem zachodzących procesów chrystianizacyjnych i akceptacji nowej wiary, ale też - mimo ogólnej zgodności z kanonami ikonografii chrześcijańskiej - pełnić funkcję tradycyjnie pojmowanego środka ochronnego przed siłami zła, czyli amuletu. Jedno zresztą nie musiało przeczyć drugiemu, a uwzględnić należałoby także chęć zamanifestowania statusu (por. nasze rozważania na temat kaptorg Kurasiński w druku). Kontekst grobowy wskazuje, że w tej podwójnej roli zawieszki były wykorzystywane przez kobiety. Ze względu na militarno-religijną wymowę ich adresatami i odbiorcami mogli być też wojownicy, choć w tym przypadku skazani jesteśmy jedynie na domysły. W tej sytuacji brakuje przesłanek do wypowiadania się na temat religijnych przekonań osób, do których omawiane zawieszki należały, ani tym bardziej do kreślenia jakichkolwiek generalizacji, licząc się z regionalnymi odmiennościami w zakresie zachodzących ówcześnie przeobrażeń religijnych.

Na zakończenie chcielibyśmy zasygnalizować jeszcze jedną kwestię. W zakomponowanej na zawieszkach scenie narzędziem walki jest włócznia wymierzona w gadzią postać znajdującą się pod kopytami konia - w strefie dolnej kojarzonej z obecnością sił chtonicznych. Nasuwa się tu skojarzenie z obserwowanym niekiedy na wczesnośredniowiecznych cmentarzyskach zjawiskiem deponowania

25 Możliwe, że nie używano ich w ogóle do spinania szat. Konstrukcja zapięcia była wielkościowo nieodpowiednia, aby utrzymać grubszy materiał, przykładowo płaszcza, natomiast w przypadku tkaniny delikatniejszej, przedmiot był zbyt ciężki i ściągałby ją w dół, tak że ozdobna powierzchnia stałaby się niewidoczna. Noszono je zapewne w dobrze widocznym miejscu wierzchniej odzieży kobiet i dzieci, przypuszczalnie jako ozdobne plakietki (być może z zawartością) (Garam 1993: 117). 
tego oręża grotem skierowanym ku stopom pochowanych osób, a zatem również ku negatywnie nacechowanemu „dołowi” (zob. Kurasiński 2or4; ostatnio na ten temat także Górewicz 2020: I23-I24). Być może mamy tu do czynienia z porównywalną ideą, aczkolwiek realizującą się i wyrażaną w odmienny sposób ${ }^{26}$. Ocena ewentualnych powiązań i zależności zachodzących pomiędzy obydwoma fenomenami wymagałaby już jednak podjęcia odrębnej analizy.

\section{Bibliografia}

Agrigoroaei V.(2011), Choix nobiliaires ou modèle oriental: le cas de saint Georges et des autres saints guerriers, [w:] M. Aurell, C. Girbea (red.), Chevalerie \& christianisme auxXII ${ }^{e}$ et XIII ${ }^{e}$ siècles, Presses Universitaires de Rennes, Rennes, s. 77-IOO, https://doi.org/10.4000/books.pur.II2955

Alpatov M.V.(1956), Obraz Georgiya-voina v iskusstve Vizantii i drevney Rusi, „Trudy Otdela drevnerusskoy literatury Instituta russkoy literatury AN SSSR", I2, S. 292-3IO.

Arkhipova Ye.I.(2015), Kamennyye ikonki so svyatymi voinami: vizantiyskoye naslediye i yuzhnorusskaya traditsiya, [w:] V.N.Zalesskaya, Ye.V.Stepanova (red.), Vizantiya $v$ kontekste mirovoy kul'tury. Materialy konferentsii, posvyashchonnoy pamyati A.V.Bank (1906-1984), Izdatel'stvo Gosudarstvennogo Ermitazha, Sankt Peterburg (Trudy Gosudarstvennogo Ermitazha, 74), s. 271-289.

Arutyunyan Yu.I.(2009), Obraz svyatogo Georgiya v srednevekovoy rytsarskoy kul'ture, „Trudy Sankt-Peterburgskogo gosudarstvennogo instituta kul'tury”, I85, s. I60-I68.

Astakhova A.M.(1958), Il'ya Muromets v russkom epose, [w:] A.M. Astakhova (red.), Il'ya Muromets, Izdatel'stvo Akademii Nauk SsSR, Moskva-Leningrad, s.393-419.

Atanasov G. (200I), Sveti Georgi Pobedonosets. Kult i obraz v pravoslavniya iztok prez srednovekovieto, Knigoizdatel'stvo Zograf, Varna.

Atanasov G. (2002), Voinskite ikonografii, vŭorŭzhenieto i snaryazhenieto na sveti Georgi prez rannoto srednovekovie ( $V-X$ v.), [w:] V. Yotov, V. Nikolov, V. Slavchev (red.), Orŭzhie i naryazhenie prez kŭsnata antichnost i srednovikovieto IV-XV v. Mezhdu-

$26 \mathrm{Z}$ najbardziej frapującą sytuacją mamy do czynienia na terenie Łotwy, skąd - jak wiemy - znany jest liczny zestaw rozpatrywanych zawieszek. Ich występowanie ogranicza się do terenów zajętych przez osadnictwo łatgalskie, gdzie na cmentarzach użytkowanych w X-XIII w. groty włóczni deponowane były głównie w okolicy stóp, zwłaszcza prawej (około $40 \%$ ) oraz na wysokości goleni (Radiņšs I999a: 107, ryc. 76-77 [wykresy]; 1999b: IIO, ryc. I6 [wykres]). Na uwagę zasługuje też płyta nagrobna z kościoła św. Marcina na wyspie Mārtiņsala (dawniej Holme) w dolnym biegu rzeki Dźwiny niedaleko Rygi, datowana na około I200 r. Przedstawiony na niej został uzbrojony mężczyzna, w lewej ręce trzymający tarczę, w prawej zaś włócznię, której grot opiera się o ziemię. Z tyłu głowy wojownika znajduje się krzyż. Wyklucza się, iż chodzić może o wizerunek rycerskiego świętego, natomiast kwestią otwartą pozostaje, czy wyobrażono chrześcijańskiego wojownika walczącego w obronie krzyża, czy też osobę dopiero przyjmującą nową wiarę. Bez wątpienia jednak płyta upamiętniała osobę o wysokiej randze społecznej (Loeffler 1929: I2-I4, ryc. I; Creutz 2003: I27-I28, ryc. I0:IO). 
narodna konferentsiya, Varna, I4-I6 septemvri 2000, Regionalen istoricheski muzer̆, Varna (Acta Musei Varnaensis, I), s. 37-58.

Atanasov G. (2010), Svyatoy Georgiy - peshiy voin-zmeyeborets: vozniknoveniye ikonografii, pamyatniki, semantika i rasprostraneniye, [w:] A.A. Peskova, O.A. Shcheglova, A.Ye. Musin (red.), Slavyano-russkoye yuvelirnoye delo i yego istoki. Materialy Mezhdunarodnoy nauchnoy konferentsii, posvyashchennoy roo-letiyu so dnya rozhdeniya Gali Fodorovny Korzukbinoy (Sankt-Peterburg, I0-I6 aprelya 2006 g.), Nestor-Istoriya, Sankt-Peterburg, s.330-343.

Barkóczi L. (1968), $A 6^{\text {th }}$ Century Cemetery from Keszthely-Fenékpuszta, „Acta Archaeologica Academiae Scientiarum Hungaricae", 20.I-4, s. 275-3II.

Bollók Á. (20I4), Bellerophon and Crucifixion? A Brief Note on Late Antique Circular Box Brooches from Pannonia, [w:] O. Heinrich-Tamáska, P. Straub (red.), Mensch, Siedlung und Landschaft im Wechsel der Jahrtausende am Balaton / People, Settlement and Landscape on Lake Balaton over the Millennia, Verlag Marie Leidorf $\mathrm{GmbH}$, Budapest-Leipzig-Keszthely-Rahdeh/Westf., s. 259-279.

Brūzis R. (2017), Sv. Jura kulta atspulgi I4.-I5. gs ieroču apbedījumos Livonijā, [w:] A.Vilcāne (red.), Letonika, diaspora un starpkultūru komunikācija. Referātu tēzes, Latvijas Universitātes Latvijas vēstures institūts, Rīga, s. Is.

Buko A. (2016), Chrześcijanie i poganie. O problemach interpretacji odkryć archeologicznych związanych z początkami chrześsijanstwa na ziemiach polskich, „Slavia Antiqua”, 57, s. 13-51, https://doi.org/10.14746/sa.2016.57.2

Chukova T.A. (2006), Ikonografiya Khrista, Bozhiyey Materi i svyatykh na drevnerusskikh metallicheskikh aktovykh pechatyakh $X-X V v v$., [w:] E.N.Nosov (red.), Khristianskaya ikonografiya Vostoka i Zapada v pamyatnikakh material'noy kul'tury Drevney Rusi i Vizantii, Peterburgskoye Vostokovedeniye, Sankt-Peterburg, s. 28-77.

Churakova A.Yu. [Kononovich A.] (2016), Priveski-obrazki sizobrazheniyem svyatogo vsadnika na territorii Drevnerusskogo gosudarstva, „Arkheologiya i istoriya Pskova i Pskovskoy zemli", 31, s. 367-374.

Churakova A.Yu. [Kononovich A.] (2017), Podveska-ikonka «Chudo sv. Georgiya o zmiye»s Gorodishcha bliz Shepetovki, [w:] A.E. Musin, O.A.Shcheglova (red.), $V$ kamne i v bronze. Sbornik statey v chest' Anny Peskovoy, Institut istorii material'noy kul'tury Ran, Nevskaya Knizhnaya Tipografiya, Sankt-Peterburg, s. 6II-6I 4 .

Cormack R., Mihalarias S. (1984), A Crusader Painting of St George: 'maniera greca' or 'ingua franca'?, „The Burlington Magazine”, 126.972, s. 132-I4I.

Creutz K. (2003), Tension and Tradition. A Study of Late Iron Age Spearheads around the Baltic Sea, Department of Archaeology, Stockholm University, Stockholm.

Daim F. (2002), Pilgeramulette und Frauenschmuck? Zu den Scheibenfibeln der frühen Keszthely-Kultur, „Zalai Múzeum”, II, s. I13-132.

Daranowska-Łukaszewska J., Jacniacka M. (1997), Jerzy z Kapadocji. Ikonografia, [w:] S. Wielgus i in. (red.), Encyklopedia Katolicka, t. viI, Towarzystwo Naukowe Katolickiego Uniwersytetu Lubelskiego Jana Pawła II, Lublin, szp. I225-I227.

Deptuła C. (2003), Archaniot i smok. Z zagadnień legendy miejsca i mitu poczatku $w$ Polsce średniowiecznej, Werset, Lublin.

Drocourt N. (2004), Les animaux comme cadeaux d'ambassade entre Byzance et ses voisins (VII ${ }^{e}-X I I^{e}$ siècle), [w:] B. Doumerc, C. Picard (red.), Byzance et ses périphéries. 
Hommage à Alain Ducellier, cnrs, Université de Toulouse-le Mirail, Toulouse, s. 67-93, https://doi.org/10.4000/books.pumi.26016

Dzik M. (2015), Przemiany zwyczajów pogrzebowych w międzyrzeczu Bugu i górnej Narwi $(X I-X V$ w.), t. I, Oficyna Wydawnicza Zimowit; Państwowe Muzeum Archeologiczne; Muzeum Podlaskie, Rzeszów-Warszawa- Białystok.

Fingerlin G. (2008), „Er soll Dir den Kopf zertreten” - Endlich komplett: das frühchristliche Bildprogramm aus dem Kammergrab von Hüfingen "Gierhalde”, „Archäologische Nachrichten aus Baden", 76-77, s. 68-69, 97.

Fingerlin G. (2012), Die ältesten christlichen Bilder der Alamannia. Zu Herkunft und Ikonographie der drei silbernen Phalerae aus dem Kammergrab von der "Gierhalde” in Hüfingen, dem Hauptort der frühmittelalterlichen Baar, „Schriften des Vereins für Geschichte der Baar", 55, s. 7-26.

Forstner D. (1990), Świat symboliki chrześcijańskiej, Instytut Wydawniczy PAX, Warszawa.

Gapski M.H.(20I4), Koń w kulturze polskiego średniowiecza, Wydawnictwo Nauka i Innowacje, Poznań.

Garam É. (1993), Die awarenzeitlichen Scheibenfibeln, „Communicationes Archaeologicae Hungariae", s. 99-134.

Gierszewska M.(2012), Smoki jako istoty mieszane. Funkcjonowanie w literaturze greckiej i rzymskiej, „Symbolae Philologorum Posnaniensium Graecae et Latinae”, 22.I, s. $167-186$.

Glaser F. (2002), Die Bildmotive der Scheibenfibeln aus Keszthely, „Zalai Múzeum”, II, S. $145-152$.

Good J. (2009), The Cult of St George in Medieval England, The Boydell Press, Woodbridge, https://doi.org/10.1017/9781846157127

Ǵorǵievski D. (2012), Prilog kon datiranjeto na viničkite terakoti, „Patrimonium”, 5.ı, S. $117-126$.

Ǵorǵievski D. [Gjorgjievski D.] (2015), Dating of the Vinica Terracotta Reliefs, [w:] Z. Dimoski, E. Lučeska, P. Borowiak (red.), Stowiańskie teksty kultury. Samokowskie kontynuacje, t. II, Instytut Filologii Słowiańskiej UAM; Institut staroslovenska kul'tura - Prilep, Makedoniya, Poznań-Prilep, s. I09-II7.

Górewicz I.D. (2020), O broni Stowian. Na wojnie i w kulturze, Triglav; Wydawnictwo Poznańskie, Szczecin-Poznań.

Grotowski P.Ł.(20II), Święci wojownicy w sztuce bizantyńskiej (843-I26I). Studia nad ikonografia uzbrojenia i ubioru, Wydawnictwo WAM, Kraków.

Grygiel J. (2007), Religijność krucjatowa, [w:] W. Szymborski, P.F. Nowakowski (red.), Religijność. Wymiar prywatny i publiczny, Księgarnia Akademicka, Kraków, s. 83-98.

Guriewicz A. (1976), Kategorie kultury średniowiecznej, Państwowy Instytut Wydawniczy, Warszawa.

Hahn S. (2001), Die Ikonographie des hl. Georg: Darstellungen im Westen Europas, [w:] S. Hahn, S. Methen, P.B. Steiner (red.), Sanct Georg. Der Ritter mit dem Drachen, Kunstverlag Josef Fink, Lindenberg, s. 77-9I.

Honneger Th. (2019), Introducing the Medieval Dragon, University of Wales Press, Cardiff. 
Immerzeel M. (2004), Holy Horsemen and Crusader Banners. Equestrian Saints in Wall Paintings in Lebanon and Syria, „Eastern Christian Art”, I, s. 29-60, https://doi.org/I0.2143/ECA.I.I.51694I

Jaskanis D. (1999), O kilku przedmiotach obcejproweniencji na wschodnim Mazowszu wczesnego średniowiecza, „Światowit. Nowa Seria”, I (42, fasc. B), s. 8I-87.

Jaskanis D. (2008), Święck. Wczesnośredniowieczny zespót osadniczy na pótnocno-wschodnim Mazowszu, SNAP Oddział w Warszawie; Muzeum Podlaskie w Białymstoku, Warszawa.

Jaszczewska (2010), Święty Jerzy w wierzeniach i przystowiach polskich, „Linguistics Applied", 2-3, s. 280-286.

Juzepczuk M. (2018), Kult świętych a zwycięstwa militarne pierwszych Piastów (od $x$ do początków XIII w.), „Saeculum Christianum”, 25, s. 63-76, https://doi.org/10.21697/ sc.2018.25.6

Karlova K.F. (2020), Set-zmeyeborets i sv. Georgiy: preyemstvennost' ikonograficheskogo tipa, [w:] N.N. Kazanskiy (red.), Indoyeuropeyskoye yazykoznaniye i klassicheskaya filologiya-XXIV (chteniya pamyati I.M. Tronskogo). Materialy Mezhdunarodnoy konferentsii, prokhodivshey 22-24 iyunya $2020 \mathrm{~g}$., t. II, Institut lingvisticheskikh issledovaniy RAN, Sankt-Peterburg, s. 1209-1224.

Katičic R. (20II), Jurjevo koplje i Jurjev mač, [w:] A. Pleterski, T. Vinšćak (red.), Perunovo koplje, Inštitut za arheologijo ZRC SAZU, Založba ZRC, Ljubljana, s. 8I-87.

Kolpakova N. (2013), Evolyutsiya ikonohrafichnykh typiv zobrazhennya sv. Heorhiya u mystetstvi Vizantiyi, „Narodoznavchi zoshyty”, 6, s. II2I-II30.

Kononovich A. [Churakova A.Yu.] (2013), Drevnerusskiye priveski-obrazki s izobrazheniyem svyatogo voina, [w:] V.N. Gur'yanov (red.), Drevnosti Sredne-Zapadnoy Rossii i sopredel'nykh territoriy. Materialy XXIX mezhdunarodnoy studencheskoy arkheologo-etnologicheskoy konferentsii 22-25 maya 2013 goda, Poligram-Plyus, Bryansk, s. 66-76.

Kozlovskiy S.V.(2016), Il'ya Muromets i yego vremya: istoriografiya i perspektivy izucheniya obraza bylinnogo geroya, [w:] A.V. Petrov (red.), Paleorosiya. Drevnyaya Rus': vo vremeni, v lichnostyakh, v ideyakh. Al'manakh, t. v, Kontrast, Sankt-Peterburg, s. 177-189.

Kóčka-Krenz H. (2002), Krzyżyki we wczesnym średniowieczu jako przejaw chrystianizacji ziem polskich. Refleksja archeologa, [w:] F. Lenort (red.), Scirptura Sacra Posnaniensis. Opuscula Mariano Wolniewicz octogenario dedicata, Wydział Teologiczny UAM, Poznań, s. 153-I61.

Kuniga I. (2000), Kristapiņu kapulauks 8. gs. beigas - I2. gs., RaKa, Rīgā.

Kurasiński T.(2014), Grotem w dót, grotem w górę. Deponowanie wtóczni w grobach wczesnośredniowiecznych na ziemiach polskich, [w:] T. Kurasińki, K. Skóra (red.), Grób w przestrzeni, przestrzeń w grobie. Przestrzenne uwarunkowania w dawnej obrzędowości pogrzebowej, Łódzkie Towarzystwo Naukowe, Łódź

(Acta Archaeologica Lodziensia, 60), s. 159-190.

Kurasiński T.(w druku), Magia - religia - ostentacja. Kaptorgi z wczesnośredniowiecznego cmentarzyska w Radomiu w ujęciu komparatystycznym, „Slavia Antiqua”, 62.

Lazarev V.N. (1953), Novyy pamyatnik stankovoy zhivopisi XII veka i obraz Georgiya-voina v vizantiyskom i drevnerusskom iskusstve, „Vizantiyskiy Vremennik”, 6, s. 186-222. 
Lazarev V.N. (1970), Novyy pamyatnik stankovoy zhivopisi XII veka i obraz Georgiya-voina v vizantiyskom i drevnerusskom iskusstve, [w:] V.N. Lazarev, Russkaya srednevekovaya zhivopis.' Stat'i i issledovaniya, Izdatel'stvo Nauka, Moskva, s. 55-IO2.

Le Goff J. (2020), Czas uświęcony. Jakub de Voragine i „Ztota legenda”, Oficyna Wydawnicza Volumen, Warszawa.

Loeffler H. (1929), Die Grabsteine, Grabmäler und Epitaphien in den Kirchen Alt-Livland vom 13.-18. Jahrhundert, Verlag der Buchhandlung G. Löffler, Riga.

Lurker M. (1989), Stownik obrazów i symboli biblijnych, Pallotinum, Poznań.

MacGregor J.B. (2004), Negotiating Knightly Piety: the Cult of the Warrior-Saints in the West, ca. I70-ca. I200, „Church History”, 73.2, s.317-345, https://doi.org/I0.1017/ So009640700109291

Maré E.A. (2004), There is no Hero Without a Dragon: A Revisionist Interpretation of the Myth of St. George and the Dragon, [w:] P.L. Yoder, P.M. Kreuter (red.), Monsters and the Monstrous. Myths and Metaphors of Enduring Evil, Inter-Disciplinary Press, Oxford, s. 179-188.

Mianecki A.(2012), Przekleństwo królów, plaga królestw - smok w wybranych opowieściach polskiego folkloru tradycyjnego, [w:] K. Konarska (red.), Powodzie, plagi, życie i inne katastrofy, Wydawnictwo Uniwersytetu Wrocławskiego, Wrocław (Colloquia Anthropologica et Communicativa, 5), s. 477-494.

Mikhaylova R. (2003), Kul't svyatykh voyiniv u Halyts'ko-Volyns'kiy Rusi (na prykladi pam”yatok prykladnoho mystetstva, „Narodoznavchi zoshyty”, I-2, s. I80-187.

Morgan G. (2006), St Gregor. Knight, Martyr, Patron Saint and Dragonslayer, Pocket Essentials, Harpenden.

Moskal' M. (2020), Tema borot'by svyatykh voyiniv zi zlom v ukrayins'komu relihiynomu mystetstvi XII-XVIII st., „Narodoznavchi zoshyty”, I.I5I, s. 220-228, https://doi.org/10.15407/nz2020.01.220

Mukhin A.S. (2009), Khtonicheskiye motivy v staroladozhskoy freske «Chudo Georgiya o zmiye», ,Trudy Sankt-Peterburgskogo gosudarstvennogo instituta kul'tury”, I85, S. $220-226$.

Musin A.E. (2007), Kamennaya ikonka sobrazom svyatogo vsadnika iz nakhodok na Novgorodskom (Ryurikovom) gorodishche 2005 g.: voprosy interpretatsii, [w:] E.N. Nosov, A.E. Musin (red.), U istokov russkoy gosudarstvennosti. $K_{3}$ o-letiyu arkheologicheskogo izucheniya Novgorodskogo Ryurikova Gorodishcha i Novgorodskoy oblastnoy arkheologicheskoy ekspeditsii. Istoriko-arkheologicheskiy sbornik. Materialy mezhdunarodnoy nauchnoy konferentsii, 4-7 oktyabrya 2005 g., Izdatel'stvo Dmitriy Bulanin, Sankt-Peterburg, s. 148-165.

Myts'ko I. (1998), Do problemy stanovlennya populyarnykh khrystyyans'kykh kul'tiv $v$ Ukrayini, „Mediaevalia Ucrainica”, 5, s. 26-43.

Nekrasova M.A. (2009), Obraz vsadnika-voina - svyatogo Georgiya zmeyebortsa. Yego sakral'nyy smysl v iskusstve slavyanskikh narodov kak istochnika zhiznennykh nachal, „Trudy Sankt-Peterburgskogo gosudarstvennogo instituta kul'tury”, I85, s. $15-27$.

Nikolayeva T.V.(1983), Drevnerusskaya melkaya plastika iz kamnya. XI-XV vv., Nauka, Moskva. 
Ovčarov N. (1991), Sur l'iconographie de St. Georges aux XI $I^{e}-X I I^{e}$ siècles, „Byzantinoslavica", 52, s. 12I-129.

Pancaroğlu O. (2004), The Itinerant Dragon-Slayer: Forging Paths of Image and Identity in Medieval Anatolia, „Gesta”, 43.2, s. 15I-164, https://doi.org/10.2307/25067102

Papp L. (1963), A nagyharsányi avarkori temetö I , „Janus Pannonius Múzeum Évkönyve”, 8 , s. II3-I4I.

Pivovarov S. (2011), Medal'yon zi suyatym vershnykom z litopysnoho Vasyleva: sproba interpretatsiyi, „Materialy i doslidzhennya z arkheolohiyi Prykarpattya i Volyni”, I5, s. 392-396.

Pollems K. (1989a), Georg [Kultverbreitung], [w:] Lexikon des Mittelalter, t. IV, Artemis Verlag, München-Zürich, szp. 1273-I274.

Pollems K. (1989b), Georg [Ikonographie in Westeuropa], [w:] Lexikon des Mittelalter, t. IV, Artemis Verlag, München-Zürich, szp. I274.

Porfiridov N.G. (1972), Drevnerusskaya melkaya kamennaya plastika i yeye syuzhety, "Sovetskaya arkheologiya”, 3, s. 200-208.

Propp V.Ya. (2002), Zmeyeborstvo Georgiya v svete fol'klora, [w:] V.Ya. Propp, Fol'klor. Literatura. Istoriya, Labirint, Moskva, s.92-II4.

Quast D. (2002), Kriegerdarstellungen der Merowingerzeit aus der Alamannia, „Archäologisches Korrespondenzblatt", 32.2, s.267-280.

Quast D. (2009), Merovingian Period Equestrians in Figural Art, „Archaeologica Baltica”, II, S. 330-342.

Radiņ̧š A. (1999a), Io.-I3. gadsimta senkapi latgalu apdzìvotajā teritorijā un Austrumlatvijas etniskās, sociālās un politiskās vēstures jautājumi. Monogrāfija, Latvijas Vēstures muzejs, Rīga.

Radin'sh A. (1999b), Pogrebal'nyy obryad i inventar' latgal'skikh zakhoroneniy Io-13 vekov, "Archaeologia Lituana”, I, s. 65-118.

Radin̄š A. (2007), Epoka żelaza, [w:] A. Bitner-Wróblewska (red.), Skarby starożytnej Łotwy / Treasures of Ancient Latvia, Państwowe Muzeum Archeologiczne w Warszawie; SNAP, Oddział w Warszawie, Warszawa, s. 155-279.

Reginskaya N.V.(2010), Sv. Georgiy Pobedonosets - nebesnyy pokrovitel' Rossii v izobrazitel'nom iskusstve Evropy i Rossii, Izdatel'stvo „SРько”, Sankt-Peterburg.

Savyts'kyy V., Svintsshch'kyy V.(2013), [w:] Istoriya ta suchasnist' Pravoslav'ya na Volyni: materialy III naukovo-praktychnoyi konferentsiyi (Luts'k, Is-I6 lystopada $20 I 2$ r.), Volyns'ka yeparkhiya UPTS, Volyns'ka dukhovna seminariya, Vydavnychyy viddil Volyns'koyi yeparkhiyi, Luts'k, s. 37-43.

Sedova M.V.(198I), Yuvelirnyye izdeliya drevnego Novgoroda (X-XVvv.), Nauka, Moskva.

Sedova M.V.(2006), Natel'nyye ikonki s izobrazheniyem Sv. Georgiya RostovoSuzdal'skoy Rusi (XI-XIII vv.), [w:] M.A. Nekrasova, E.K. Guseva, K.K. Kuznetsova (red.), Georgiy Karlovich Vagner - uchenyy, khudozhnik, chelovek, Institut mirovoy literatury im. A.M. Gor'kogo RAN, Moskva, s. 24I-25I.

Shevelev V.V.(2005), Gromovye strely” proroka Il'ia. Etnograficheskie realii, „Zhivaya starina", I, s. 2-3. 
Shtepanovskaya E.M. (2009). Bitva gromoverzhtsa so zmeyem: istoki obraza Georgiya Pobedonostsa $v$ indoyevropeyskoy mifologii, „Trudy Sankt-Peterburgskogo gosudarstvennogo instituta kul'tury", 185, s.212-219.

Sikorski M. (2015), Smoki i smokobójstwo, Wydawnictwo Sativa Studio, Stradunia.

Snelders B., Jeudy A. (2006), Equestrian Saints in Egypt and North Mesopotamia, „Eastern Chrostian Art”, 2, s. IO5-I42.

Sobolev V.Yu. (2017a), Ikonki-priveski s konnym izobrazheniyem svyatogo Georgiya, [w:] A.E. Musin, O.A. Shcheglova (red.), v kamne i v bronze. Sbornik statey v chest' Anny Peskovoy, Institut istorii material'noy kul'tury RAN, Nevskaya Knizhnaya Tipografiya, Sankt-Peterburg, s. 537-547.

Sobolev V.Yu. (2017b), Svyatoy Georgiy. Ikonografiya odnogo tipa ikonok i snaryazheniye vsadnika i konya XII-XIII vv., [w:] A.V. Aranovich, D.Yu. Alekseyev (red.), Istoriya voyennogo kostyuma: ot drevnego mira do nashikh dney. Materialy II Mezhdunarodnoy voyenno-istoricheskoy konferentsii, Sankt-Peterburg, Ig noyabrya zors g., Sankt-Peterburgskiy gosudarstvennyy universitet promyshlennykh tekhnologiy i dizayna, Sankt-Peterburg, s. 29-50.

Sobolev V.Yu. (2019), Rannesrednevekovyye ikonki-priveski. Obraztsy i podrazhaniya, "Aktual'nyye problemy teorii i istorii iskusstva”, 9, s. 429-438, 835-836.

Spirgis R. (2019), Nakhodki ikonok sizobrazheniyem Sv. Georgiya na territorii Latvii, "Arkheologiya i istoriya Pskova i Pskovskoy zemli", 34, s.314-334.

Staecker J. (1997), Legends and Mysteries: Reflections on the Evidence of the Early Mission in Scandinavia, [w:] H. Andersson, P. Carelli, L. Ersgård (red.), Visions of the Past. Trends and Traditions in Swedish Medieval Archaeology, Central Board of National Antiquities, Lund-Stockholm, s. 419-454.

Stangé-Zhirovova N. (1992), Narodnaya i knizhnaya traditsiya pochitaniya sv. Georgiya na Rusi: opyt istoriko-etnograficheskogo analiza, „Revue des études slaves”, 64.2, s. 323-330, https://doi.org/10.3406/slave.1992.6046

Stanyukovich A.K. (2011), Neizvestnyye pamyatniki russkoy metalloplastiki. Miniatyurnyye ikonki-priveski XI-XVI vekov, Gruppa Iskateli, Moskva.

Stepanenko V.P. (2000), Obraz svyatogo Georgiya-vsadnika v Vizantiyskoy i drevnerusskoy sfragistike domongol'skogo perioda, „Problemy istorii Rossii”, $3,106-117$.

Stepanenko V.P. (2019), K ikonografii svyatykh voinov-vsadnikovv vizantiyskoy sfragistike: sv. Georgiy, „Antichnaya drevnost' i sredniye veka”, 47, s. 72-82, https://doi.org/10.15826/adsv.2019.47.005

Stepanenko V.P. (2020), Obraz sv. Georgiya-drakonobortsa na pechati M-8750 iz sobraniya Gosudarstvennogo Ermitazha, „Antichnaya drevnost' i sredniye veka”, 48, s. 290-300, https://doi.org/10.15826/adsv.2020.48.018

Swastek J. (1997), Jerzy z Kapadocji, [w:] S. Wielgus i in. (red.), Encyklopedia Katolicka, t. VII, Towarzystwo Naukowe KUL, Lublin, szp. I219-I22I.

Szczepanik P. (2015), Wojenne wyprawy Świętowita. Mit i jego materialne wyobrażenie, [w:] Migracje. Podróże w dziejach. Starożytność i średniowiecze. Monografia oparta na materiatach z VII Międzynarodowej Sesji Naukowej Dziejów ludów Morza Battyckiego, Wolin, 26-28 lipca 2014, M. Franz, K. Kościelniak, Z. Pilarczyk (red.), Toruń (Mare Integrans. Studia nad dziejami wybrzeży Morza Bałtyckiego, 7), s. 175-188. 
Szczepański S. (2010), Kamień i skata w mitologii, wierzeniach i obyczajowości ludów indoeuropejskich, [w:] R. Klimek, S. Szczepański (red.), Kamienie w historii, kulturze i religii, Robert Klimek, Olsztyn, s. 7-23.

Ters'kyy S.V.(2016), Kul't svyatykh voyiniv ta viys'kovi vidznaky u Halyts'ko-Volyns'komu viys'ku, „Viys'kovo-naukovyy visnyk”, 25, s. 59-74.

Totev K. (2020), Srednevekovyye vizantiyskiye svintsovyye ikony iz severo-vostochnoy Bolgarii (K ikonografii Svyatogo Georgiya-drakonobortsa), „Materialy po arkheologii, istorii i etnografii Tavrii", 7, s. 362-369.

Tóth E. (1999), Kereszténység a honfoglalás elötti Kárpát-medencében, [w:] É.M. Fülöp, J. Kisné Cseh (red.), Magyarok térben és időben. Nemzetközi Hungarológiai Konferencia, Tatabánya - Esztergom 19g6. május 28-31, Komárom-Esztergom Megyei Önkormányzat Múzeumainak Igazgatósága, Tata, s. 163-182.

Tóth E. (2005), Zur Herkunft und Ikonographie der Scheibenfibeln der Keszthely-Kultur, "Zalai Múzeum”, I4, S. 183-202.

Tóth E. (2013), Titkos keresztények az avar korban?, [w:] O. Tóth, P. Forisek (red.), Ünnepi kötet Gesztelyi Tamás 7o. születésnapjára, Debreceni Egyetem Történelmi Intézete, Debrecen, s. 203-220.

Tuan Y. (1987), Przestrzeń i miejsce, Państwowy Instytut Wydawniczy, Warszawa.

Tyanina E.A.(2018), K voprosu o kul'te Peruna v Novgorodskoy zemle (po materialam arkheologicheskogo issledovaniya Novgoroda), „Colloquia Russica”, I.8, s.59-72.

Usikova L.S. (2015), Obraz Heorhiya Peremozhtsya u vizantiys'kiy ta kyyevorus'kiy ikonohrafiyi, „Visnyk Natsional'noyi akademiyi kerivnykh kadriv kul'tury i mystetstv”, 4, s. 134-139.

Vaday A. (2013), The Representation of a Saint on Horseback and the Archangel from the Avar Period, „Hungarian Archaeology”, s. I-3.

Vanderheyde C. (2012), La monture des saints cavaliers dans l'art byzantin, [w:] S. Lazaris (red.), Le cheval dans les sociétés antiques et médiévales. Actes des journées d'étude internationales organisées par l'UMR 7044 (Étude des civilisations de l'Antiquité) Strasbourg, 6-7 novembre 2009, Brepols, Turnhout (Bibliothèque de l'Antiquité Tardive, 22), S. 20I-2II, https://doi.org/IO.I484/M.BAT-EB.5.I00773

Vereshchagina N. (2019), Khristianskiye kul'ty i relikvii drevnego Kiyeva (konets X-pervaya tret'XIII v.). Monografiya, Astroprint, Odessa.

Vida T.(2002), Heidnische und christliche Elemente der awarenzeitlichen Glaubenswelt, Amulette in der Awarenzeit, „Zalai Múzeum”, 11, s. 179-209.

Walter Ch. (1995), The Origins of the Cult of Saint George, „Revue des études byzantines”, 53, s. 295-326, https://doi.org/10.3406/rebyz.1995.1911

Walter Ch. (2003), The Warrior Saints in Byzantine Art and Tradition, Routledge, London-New York.

Watkins C. (1995), How to Kill a Dragon. Aspects of Indo-European Poetics, Oxford University Press, New York-Oxford.

White M. (2013), Military Saints in Byzantium and Rus, 900-I200, Cambridge University Press, New York, https://doi.org/10.1017/Св09781139013864

Zając P. (2003), „Nadprzyrodzone” w kulturze ludowej, [w:] E. Przybył (red.), Nadprzyrodzone, Nomos, Kraków, s. 85-98. 
Zhyshkovych V.(1999), Plastyka Rusi-Ukrayiny. X-persha polovyna XIV stolit', Instytut narodoznavstva, L'vov.

Żółkowska J. (2010), Funkcja dewocjonaliów chrześcijańskich na przyktadzie wybranych grobów na cmentarzyskach wczesnośredniowiecznych i nowożytnych, [w:] W. Dzieduszycki, J. Wrzesiński (red.), Tak więc po owocach poznacie ich, snap Oddział w Poznaniu, Poznań (Funeralia Lednickie, I2), s. 241-249.

Żółkowska J. (2012), Disc Pendants with St. George's Image from the Early Mediaeval Period in Poland, [w:] M. Salamon, M. Wołoszyn, A. Musin, P. Špehar, M. Hardt, M. P. Kruk, A.Sulikowska-Gąska (red.), Rome, Constantinople and Newly Converted Europe. Archeological and Historical Evidence, t. II, Geisteswissenschaftliches Zentrum Geschichte und Kultur Ostmitteleuropas e.V., Leipzig; Instytut Archeologii i Etnologii Polskiej Akademii Nauk w Warszawie; Instytut Archeologii Uniwersytetu Rzeszowskiego, Kraków-Leipzig-Rzeszów-Warszawa, s. 193-202.

Żółkowska J. (2016), Przyczynek do badań nad wczesnośredniowiecznymi zawieszkami z wizerunkami przypisywanymi św. Jerzemu. Znaleziska z obszaru Polski, „Materiały i Sprawozdania Rzeszowskiego Ośrodka Archeologicznego", 37, s. 247-278, https://doi.org/10.15584/misroa.2016.37.12

Żółkowska J. (2017), Zawieszka z wizerunkiem Matki Boskiej Orantki, [w:] A.E. Musin, O.A. Shcheglova (red.), V kamne iv bronze. Sbornik statey v chest' Anny Peskovoy, Institut istorii material'noy kul'tury RAN, Nevskaya Knizhnaya Tipografiya, Sankt-Peterburg, s. 193-199.

\section{Summary}

This article is an attempt to interpret the iconographic and semantic content encoded in disc pendants with equestrian images attributed to St George fighting the snake-dragon. They are known mainly from the northern and north-eastern Rus' lands (end of the $\mathrm{II}^{\text {th }}-\operatorname{mid} \mathrm{I}^{\text {th }}$ century), as well as Poland (mid- $\mathrm{I}^{\text {th }}-$ first half of the $13^{\text {th }}$ century) and Latvia (end of the $\mathrm{I}{ }^{\text {th }}-\mathrm{I} 4^{\text {th }}$ centuries). They were created in accordance with the canons of Christian iconography, to show both God's power and the power of the saint. At the same time, their content reaches deeper layers of meaning, related to the representation of the cosmic duel between the primal forces identified with chaos and destruction and striving to introduce a social and civilization order. The iconographic program shown on these subjects can be read as a Christianized visualization and update of the motif which is a mythical representation of God's confrontation with evil. The archetypal meaning of the struggle of opposing forces is contained in the painting of St George triumphing over evil and darkness. In the drakomachia scene depicted on the pendants, the weapon directed at the reptilian figure under the horse's hooves is a spear. Therefore, it is a spearhead directed at the negatively valorized zone. In line with the spatial valorization of the world, the "bottom" opposed to the "top" was associated with the presence of chthonic forces.

The religious-symbolic and mythological meaning of the content presented on the pendants in question indicates their syncretic character. These objects, as devotional items, could be a testimony to the ongoing processes of Christianization and the acceptance 
of the new faith, but also - despite their general compliance with the canons of Christian iconography - serve as a traditionally understood protective measure against the forces of evil, i.e. an amulet. One, moreover, did not have to contradict the other, and the willingness to manifest one's status must also be taken into account. The funerary context indicates that the pendants were used by women in this dual role. Due to the military-religious significance, their addressees and recipients could also be warriors, although in this case we can only guess that.

Keywords: early Middle Ages, pole arms, St Georg the dragon-slayer, grave goods, pendants with a warrior saints, snake-dragon theme

\section{Tomasz Kurasiński}

Instytut Archeologii i Etnologii Polskiej Akademii Nauk. Oddział w Łodzi

Ośrodek Badań nad Dawnymi Technologiami

e-mail: tomasz.kurasinski@wp.pl

(c) by the author, licensee University of Lodz - Lodz University Press, Łódź, Poland. This article is an open access article distributed under the terms and conditions of the Creative Commons Attribution license CC-BY-NC-ND 4.0 (https://creativecommons.org/licenses/by-nc-nd/4.0/) 